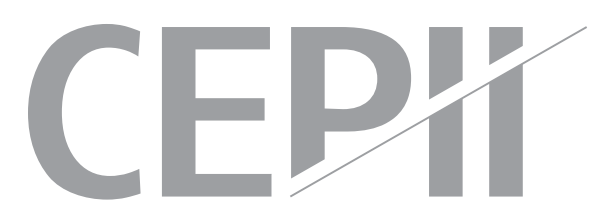

\title{
Do Visas Hinder International Trade in goods?
}

Camilo Umana-Dajud

\section{Highlights}

- I show that visas have a large negative impact on bilateral trade flows.

- The negative impact of visas is much larger for differentiated than for homogeneous products.

- Visas reduce the number of new products exported to a given market.

- Removing visas would increase welfare by nearly $10 \%$ for some sub-Saharan African countries and by $1,5 \%$ on average for developing countries. 


\section{Abstract}

Travel visas impose additional costs to firms when engaging in international trade. This paper exploits a natural experiment provided by Schengen agreements to document a causal impact and examine how much trade in goods is affected. I show that visas have a large negative impact on bilateral trade flows. The introduction of a visa to enter the Schengen Space considerably reduced bilateral trade flows between Ecuador and Bolivia and members of the Schengen space. I also find that the negative impact of visas is much larger for differentiated than for homogeneous products and that visas reduce the number of new products exported to a given market. By applying a general equilibrium framework, the paper shows that removing visas would increase welfare by nearly $10 \%$ for some subSaharan African countries and by 1,5\% on average for developing countries. For policy makers this paper highlights the importance of including visa facilitation schemes into the provisions of trade agreements and other economic partnerships.

\section{Keywords}

International Trade, Trade Costs, Visas.

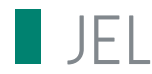

F14, F23, F63.

\section{Working Paper}

\section{CEPI}

CEPII (Centre d'Etudes Prospectives et $d^{\prime}$ 'Informations Internationales) is a French institute dedicated to producing independent, policyoriented economic research helpful to understand the international economic environment and challenges in the areas of trade policy, competitiveness, macroeconomics, international finance and growth.
CEPII Working Paper

Contributing to research in international economics

(c) CEPII, PARIS, 2016

All rights reserved. Opinions expressed in this publication are those of the author(s) alone.

$\begin{array}{ll}\text { Editorial Director: } & \text { CEPII } \\ \text { Sébastien Jean } & \text { 113, rue de Grenelle } \\ & 75007 \text { Paris } \\ \text { Production: } & +33153685500 \\ \text { Laure Boivin } & \text { www.cepii.fr } \\ \text { No ISSN: } 1293-2574 & \text { Press contact: presse }\end{array}$




\title{
Do visas hinder international trade in goods?
}

\author{
Camilo Umana Dajud
}

\section{Introduction}

A great number of non-tariff barriers have been thoroughly studied. Visas however, understood as a non-tariff trade barrier, have to the best of our knowledge not received much attention in the economic literature. This occurs despite the claims of a number of developing countries regarding the difficulties imposed by visas on their exporters.

Figure 1 shows for example the world as seen by Ethiopian nationals when planning to travel abroad. The countries in red are those countries that require Ethiopian citizens to apply for a visa prior to arrival. While there is a much reduced number of visa-free countries for Ethiopians, most of these countries are not connected to Addis Ababa through direct flights. All the countries in which connecting flights take place require transit visas for Ethiopians. It should also be highlighted that Ethiopia is not the country suffering the most from visa restrictions. There is a number of countries whose nationals can travel to even fewer countries visa free.

There are two main reasons why visa restrictions might affect international trade in goods. First, there is recent empirical evidence of the importance of face to face contact in international trade (e.g. Cristea (2011), Oxford Economics (2012)). Visas may thus reduce international trade by hindering or impeding the exports of firms whose managers or owners cannot travel to conduct business. A recent survey conducted by Oxford Economics shows the importance given to in-person meetings by firms when engaging in exporting. Figure 2 is taken from this survey. It shows the conversion rate from prospective customers to costumers with and without in-person meetings. The results were obtained using the answers to a survey conducted among 300 executives and 500 business travelers. According to the obtained answers, the percentage of prospective customers who become actual customers nearly triples when an in-person meeting takes place. 
Figure 1: Visa restrictions for an Ethiopian national

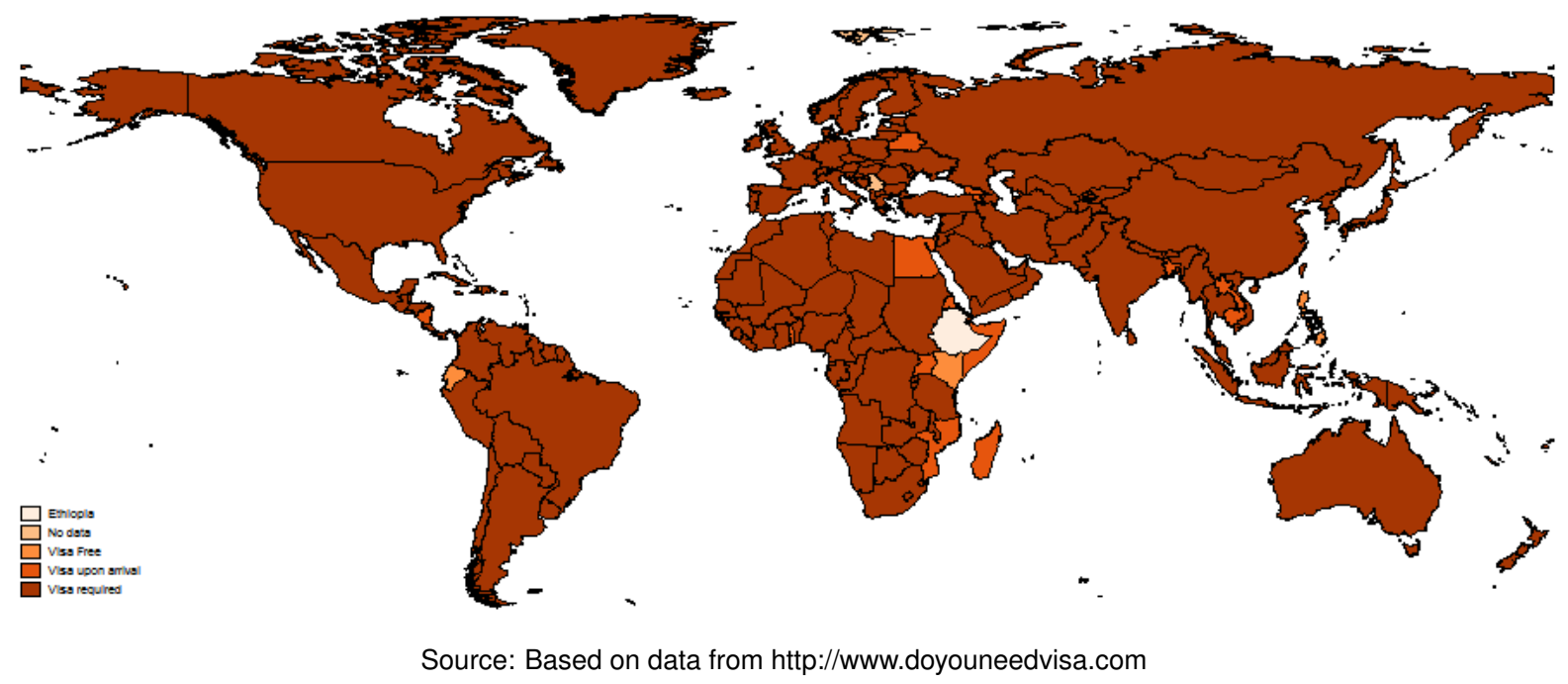

Note: This map shows short-stay visa requirements for Ethiopian citizens by destination country

Figure 2

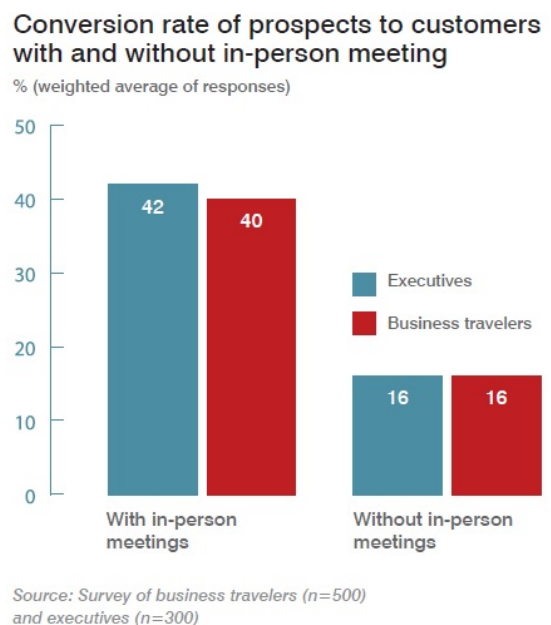

Source: Oxford Economics USA (2010), "The Return on Investment of U.S. business travel."

Note: This graph is taken from a recent Oxford Economics survey on business travels. It shows the conversion rate of potential customers into actual consumers with and without in-person meetings. The average customer conversion rate is around three times higher with face to face meetings than without them.

Second, by imposing an additional cost to firms, both in terms of time and resources, visas might make firms less competitive when compared to firms from countries whose nationals do not need visas to enter a given market. Visa appointments, in many cases, take several months and decisions can take a long time. A long delay in time could hamper business deals and impose additional risks for the buyer in terms of the seller's capacity to respect the terms of 
the contract. Moreover, for firms not located in capital cities where consulates and embassies are usually found the costs might be even higher ${ }^{1}$. Finally, visas are sometimes issued for short periods of time. For example, one year is the maximum recommended length for short stay visas in the Schengen area. Applying for a visa repeatedly can be extremely burdensome. Figure 3 shows that most business deals require more than a single business travel to be competitive. Visas can therefore constitute a considerable burden.

Figure 3

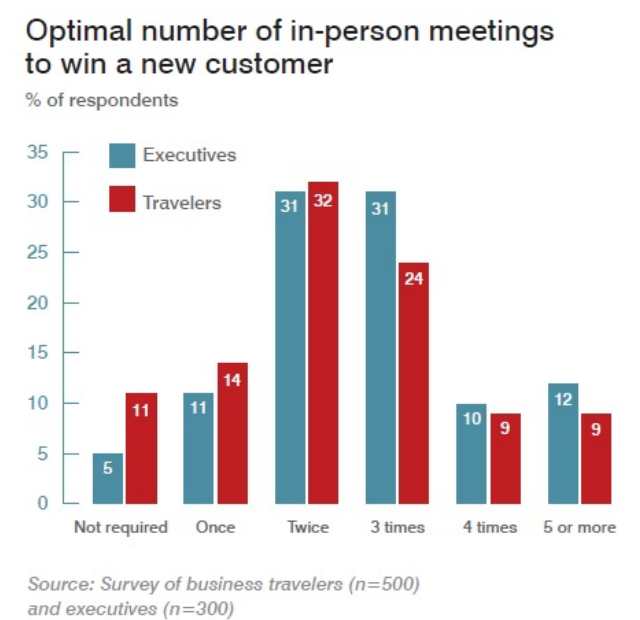

Source: Oxford Economics USA (2010), "The Return on Investment of U.S. business travel."

Note: This graph taken from Oxford Economics' survey on business travels shows the optimal number of in-person meetings for potential customer to become an actual customer. The average optimal number of face to face meetings is around 2,4.

While it can be considered that the Internet has reduced the concerns of these travel impediments, the survey conducted by Oxford Economics shows that firms consider virtual meetings to be much less effective than in-person meetings (Figure 4). This seems to be particularly the case for meetings where the purpose is to gain new customers.

\footnotetext{
${ }^{1}$ The argument becomes even stronger in such cases where there are no diplomatic representations in a given country
} 
Figure 4

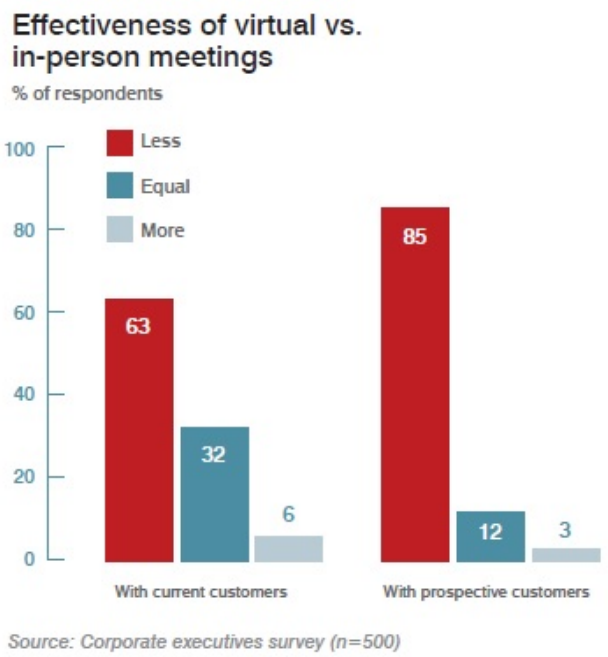

Source: Oxford Economics USA (2010), "The Return on Investment of U.S. business travel."

Note: This graph taken from Oxford Economics' survey on business travels. The chart shows the effectiveness of in person and virtual meetings both for current and potential customers. $85 \%$ of the survey's respondents answered that in-person meetings are more effective than virtual meetings. The figure decreases to $63 \%$ for current customers.

Another important feature of visas is their sharp asymmetry. While there are several other trade barriers which can be considered asymmetrical, such as phytosanitary requirements, visas are probably the most asymmetric among them. Figure 5 shows the number of destinations that can be accessed by nationals from each country.

Figure 5: Number of visa-free destinations

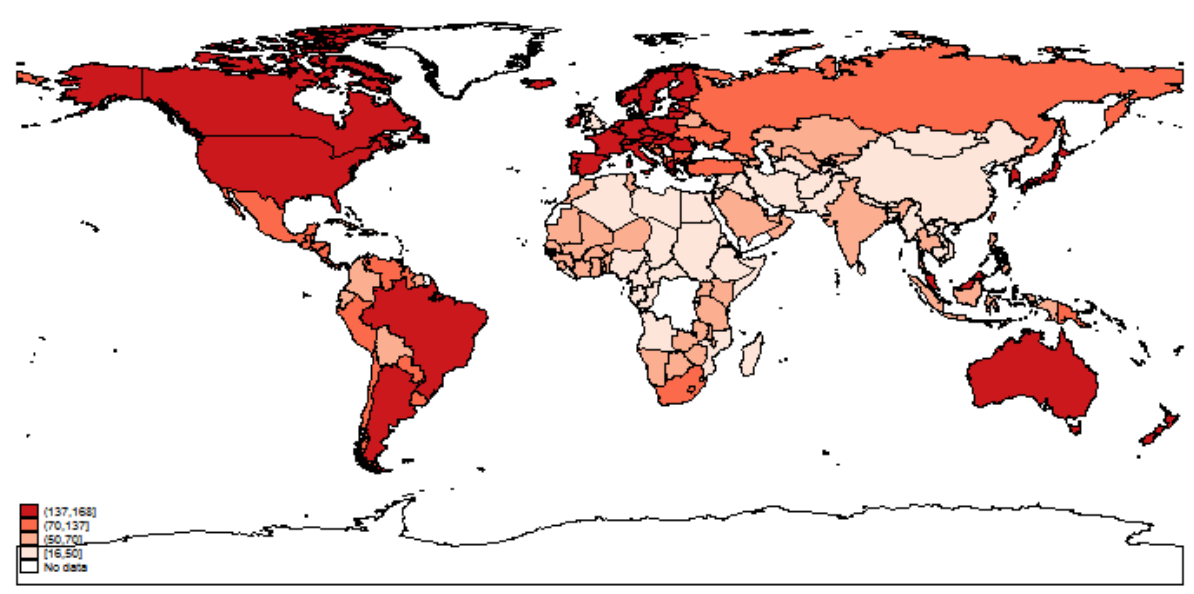

Source: Author's own calculations based on Henley and Partners' Visas Restriction Index

Note: This map is based on Henley and Partners' Visas Restriction Index which captures the number of countries a national of a another country can travel to visa free for business purposes. Nationals from OECD countries and some Latin American countries can travel visa-free to the largest number of destinations. 
Figure 6 plots the log of per capita income against the log of visa free destinations for each country. It can be clearly seen that the number of visa free destinations for nationals of a given country is strongly positively correlated with per capita income. In order words, visas appear to be a much heavier burden for poorer countries.

Figure 6: Number of visa-free destinations

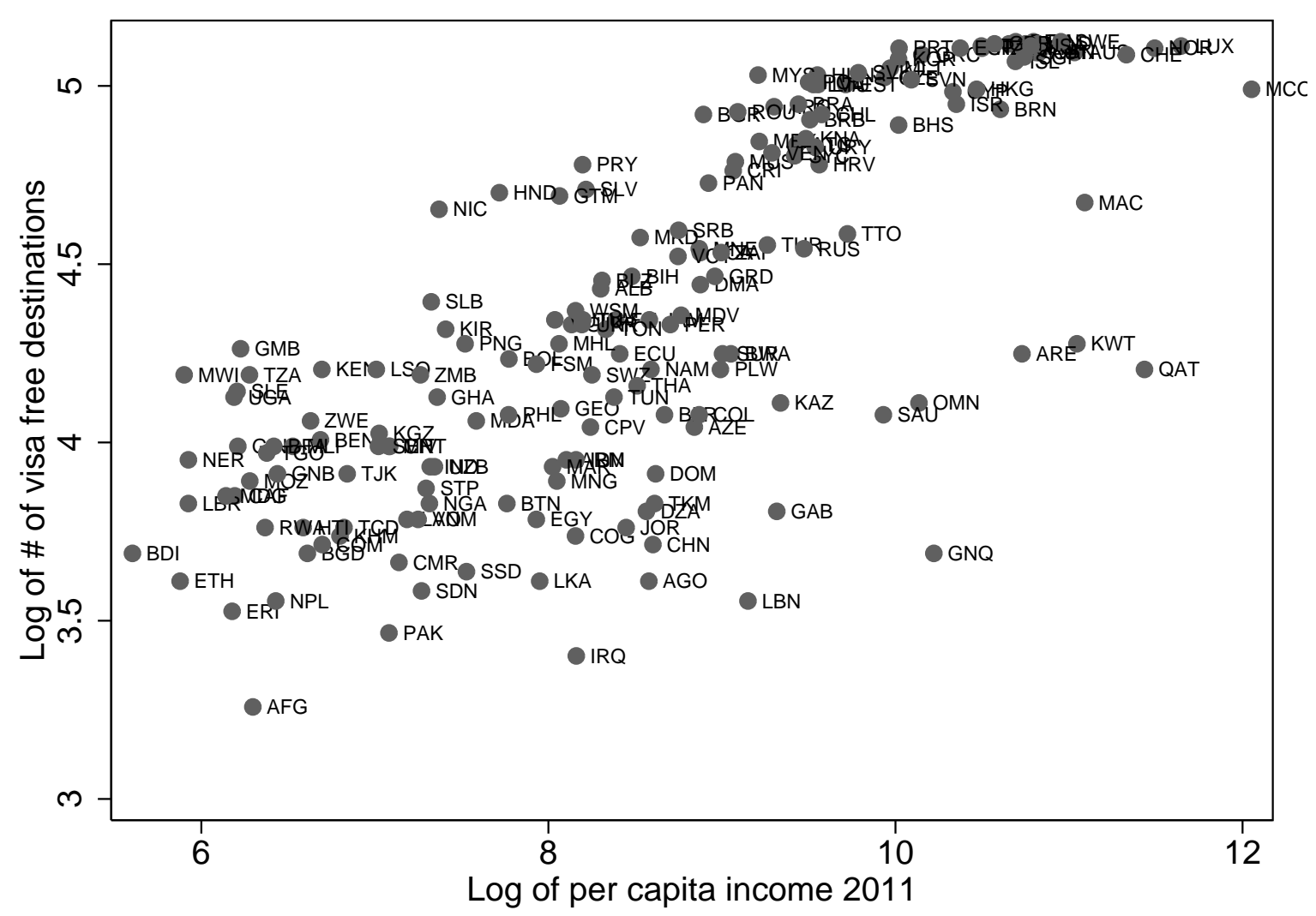

Note: This figure plots countries' log of GDP per capita (WB Development Indicators 2011) against the log of Henley and Partners' Visas Restriction Index.

Examining the causal impact of visas on trade flows faces however a number of endogeneity challenges. To address these concerns I exploit here a natural experiment provided by the Schengen Agreements. As a consequence of eliminating border controls, Schengen members adopted a common visa policy. This common visa policy entailed the adoption of third countries negative and positive lists. Nationals of countries placed in the negative list are required to apply for a visa prior to arrival to the territory of any Schengen member country. To examine the causal impact of visas I use two modifications introduced to the negative and positive lists. Ecuador and Bolivia were shifted from the positive list to negative list following a request by Spain to its Schengen partners. As explained below none of the other members of the Schengen Area were part of this request. The introduction of visas between Schengen Members, other than Spain, and Ecuador and Bolivia can therefore be seen as exogenous shocks. 
The paper is organized as follows. The next section briefly reviews the previous literature on the subject. Section 3 discusses the theoretical framework linked to the empirical exercise. Section 4 describes the details of the empirical setting that provides the natural experiment. Section 5 presents the estimation strategy and the main results. Section 6 examines the impact of visas on differentiated and homogeneous products, section 7 documents the effect on the number of exported products and section 8 presents the results of placebo tests. Section 9 performs a general equilibrium and welfare analysis. Section 10 concludes.

\section{Literature Review}

Despite, or perhaps due to, the clear asymmetrical character of visa restrictions almost no research has been devoted to the subject. One notable exception is the paper by Neumayer (2011) which estimates the effect of visa restrictions on bilateral trade flows and foreign direct investment stocks by employing a standard gravity-type model. Neumayer (2011) constructs a measure of visa restrictions that is time invariant and finds a fairly important negative effect on bilateral trade flows and FDI stocks. However, his analysis presents some shortcomings.

First, the author argues that his measure of visa does not permit including pair fixed effects or time-variant nation fixed effects in the estimations because there is no variation of this measure over the time dimension. Subsequently, he does not solve the problem of multilateral resistance terms or unobserved heterogeneity and his estimates are thus potentially biased. This has been recognized in empirical trade literature as one of the major problems of many implementations of the gravity equation.

Second, an empirical assessment of this issue faces manifestly the problem of the endogeneity of visa restrictions. In particular, it is plausible that countries might impose visas to countries with whom bilateral relationships are deteriorating and this might in turn impact trade flows. Similarly, countries might not want to impose visa restrictions between each other when trade is increasing or when bilateral trade flows are important. Reverse causation might therefore bias the results.

The questions concerning the causal impact of visas on bilateral trade and the extent to which they do remain therefore virtually unanswered. Moreover, the study of visas can shed light upon whether face to face contact is important for trade as some recent evidence seems to suggest. For example Cristea (2011) but also Poole (2010) study the effect of business travels on internal and international trade in the US. Similarly, Kulendran and Wilson (2000) and Shan and Wilson (2001) perform a similar analogous exercise for Australia and China respectively.

Lastly, there is an increasing literature on the link between migration and trade. There is a number of recent papers documenting a positive correlation (Rauch and Trindade (2002), Gould (1994), Chen and Jacks (2012)). Genc, Gheasi, Nijkamp, and Poot (2012) compile 48 different papers studying the pro-trade effect of migration. A meta-analysis performed in this paper 
shows that a $1 \%$ increase in immigration leads to an average $0.15 \%$ increase in trade between the origin and host countries. Parsons and Vézina (2014) use the exodus of Vietnamese Boat People to the U.S. to establish the causal impact of migration and trade. The natural experiment confirms the positive correlation between variables and provides evidence on the causal link. However, the causal impact that I document in this paper is not directly related to migration. Migration flows between the countries in the natural experiment used in this paper are, as explained in section 4, orthogonal to the introduction of a visa (Tables 2 and 1). The effect of visas examined here should therefore be interpreted as additional to any impact originating in the change in immigration subsequent to the introduction of a visa.

\section{Theoretical framework}

What should be the expected impact of a visa restriction according to theoretical models? When using the theoretical model that has become the workhorse of international trade, the answer is unambiguous. In models with heterogeneous firms where the productivity of firms is Pareto distributed and where there is a fixed production cost component, the answer is straightforward: the elasticity of aggregate bilateral flows is negative to both variable and fixed costs. However, should differentiated goods be more sensitive to the introduction of a visa than homogeneous goods? The answer here depends then on whether visas act as variable or fixed trade costs. In a Melitz-Chaney model, the utility function is defined by [Chaney (2008)]:

$$
U=q_{0}^{\mu_{0}} \prod_{h=1}^{H}\left(\int_{\Omega_{k}} q_{h}(\omega)^{\sigma_{h}-1 / \sigma_{h}} d \omega\right)^{\left[\sigma_{h} /\left(1-\sigma_{h}\right)\right] \mu_{h}}
$$

where there are $\mathrm{H}$ sectors of differentiated goods and a single homogenous good. $q_{0}$ is the consumption of the homogeneous good 0 and $q_{h}(\omega)$ the consumption of each variety $v$ of good $h$. $\sigma$ is the elasticity of substitution between two varieties of goods from sector h. The cost of $q$ units of a differentiated good sold in $j$ and produced in $i$ is given by:

$$
c_{i j}^{h}(q)=\frac{w_{i} \tau_{i j}^{h}}{\varphi} q+f_{i j}^{h}
$$

where $f_{i j}^{h}$ is a fixed cost faced by a firm from sector $h$ and country $i$ when exporting to country j. $\varphi$ is the unit labor productivity of the firm and $w_{i}$ is the wage in country $\mathrm{i} . \tau_{i j}^{h}$ is the iceberg cost of sending a differentiated good of sector $h$ from country $i$ to country $j$.

We define the elasticity of aggregated bilateral exports to variable and fixed costs respectively as $T \equiv-\frac{d \ln X_{i j}}{d \ln \tau_{i j}} \quad$ and $F \equiv-\frac{d \ln X_{i j}}{d \ln f_{i j}}$. It can be then shown that [Chaney (2008)]:

$$
\frac{\partial T}{\partial \sigma}=0 \quad \text { and } \quad \frac{\partial F}{\partial \sigma}<0
$$

Therefore if visas act as a variable trade costs they should impact equally the exports of homogeneous and differentiated goods. Meanwhile evidence provided by the survey conducted by Oxford Economics points to visas acting as fixed rather than variable trade costs. The survey 
highlights indeed the importance of business travels to gain new customers, which can be interpreted as a fixed cost. Therefore, as we move towards more differentiated goods the impact of an increase in fixed costs becomes larger and thus the introduction of a visa should exert a stronger impact on differentiated goods.

\section{The Schengen area as a natural experiment}

Unobserved variables may affect the probability of the introduction of a visa between two trading partners. This might lead to a selection bias and thus hinder the estimation of the effect of visas. An example of such variables is migration. There is well established evidence on the impact of immigration on trade [e.g. Head and Ries (1998), Girma and Yu (2002), Parsons and Vézina (2014)]. If those countries whose nationals are more prone to migrate are selected for visa requirements, then the assessment of the impact of visas on trade might be positively biased. Other unobserved factors might of course also affect the probability of the introduction of a visa between two trading partners.

In order to offer an answer to this question and avoid the pitfalls of previous research I exploit some features of the Schengen Agreement as a natural experiment. The Schengen agreement was signed in 1985 with the goal of creating a borderless area between 5 European countries $^{2}$. The agreement then led to the creation of the Schengen Area in 1995 encompassing the territory of seven European countries: Austria, Belgium, France, Germany, Greece, Italy, Luxembourg, and the Netherlands. Progressively, new countries, including new members of the European Union ${ }^{3}$ but not exclusively, signed the Schengen Agreement. Today the Schengen Area consists of the territories of 26 European countries.

The agreement abolished border controls among the signatory States. Naturally, the agreement included the adoption of a common visa policy. The latter led to the introduction of positive, EC 539/2001 Annex II, and negative, EC 539/2001 Annex I, country lists in 2001. The negative list enumerates all the countries whose nationals are required to obtain a visa, prior to arrival, to enter any of the Schengen Area countries. The changes introduced to these two lists have been since then extremely limited. A few Latin American countries have however shifted from the positive list to the negative one.

Among these few changes in the positive and negative lists, I will use the shifts of Ecuador and Bolivia from the positive list to the negative list. I choose these two changes in the list for two reasons. The first one is because they take place on years, 2003 and 2007, for Ecuador and Bolivia, respectively, at which the Schengen Area already counted a considerable number of members.

\footnotetext{
${ }^{2}$ This first five members of the Schengen Agreement were Belgium, France, Germany, Luxemburg and the Netherlands.

${ }^{3}$ with the exception of the newest members-Bulgaria, Croatia and Romania which are not yet part of the Schengen Space.
} 
The second and most important consideration is the reason of the introduction of these visa measures. In order for a third country to be included in the negative list, the European Commission has to propose an amendment to Council Regulation 539/2001 based on the request of a member state. The Council of the European Union has then to adopt the amendment by consensus ${ }^{4}$. A particular feature of the decision making process is that the states requesting the amendment and the deliberations of the European Council to the lists have not been made public.

Spain maintains particular links with its former colonies due to historical and cultural reasons but also because these countries have been traditional destinations for Spanish migrants. As a consequence, Spain had treaties which forbid the requirement of visas for nationals of these countries. When Spain introduced visa requirements for Colombian nationals in 2001, the decision was widely debated and stirred up public opinion in Spain and in most of the lberoamerican countries. At the time when the decision was adopted an open letter was addressed to the Spanish prime minister by a number of prominent Latin American intellectuals among whom the Nobel prize laureate Gabriel Garcia Marquez ${ }^{5}$.The letter obtained the support of a great number of Spanish intellectual and political figures ${ }^{6}$.

Eager to avoid a similar debate when introducing visas for Ecuadorian and Bolivian nationals in 2003 and 2007 respectively, the Spanish government tried to suggest that the introduction of a visa was a request coming from its European partners. This however caused a debate among Spanish officials which, paradoxically, made clear that Spain had requested the European Council to amend Council Regulation 539/2001. This fact was made public by a declaration of the Spanish government delegate for migratory matters ${ }^{7}$.

The main justification for the introduction of visas in these two cases was the increasing immigration originating in Bolivia and Ecuador ${ }^{8}$. Tables 1 and 2 offer evidence for the hypothesis that the introduction of visas for Ecuadorians and Bolivians was pushed for exclusively by Spain. As it can be observed in table 2 Ecuadorian immigration is significant only in Spain. Moreover, a considerable reduction of immigration, which was the main goal of the introduction of visas, is observed only in Spain in 2004 and not in other members of Schengen Space. The same is true for Bolivian immigration. Similarly, Table 1 shows that Spain is the only significant immigration destination country for Bolivian nationals in Europe. Once again, Spain is the only country where the introduction of the visa requirement reduces immigration. As mentioned above, Bolivian and Ecuadorian immigration was considerable in Spain due to strong cultural

\footnotetext{
${ }^{4}$ The rule establishes a majority vote, however, reaching a consensus has been adopted as a regular practice. The European Parliament has now the same power of decision as the Council of the European Union. This was not however the case when Ecuador and Bolivia shifted to the negative list. At that time the European Parliament voted the amendments to Council Regulation 539/2001 but the vote had only a 'consultation value'.

${ }^{5} \mathrm{http}: / /$ www.jornada.unam.mx/2001/03/19/028n1mun.html

${ }^{6} \mathrm{http}: / /$ elpais.com/diario/2001/03/23/espana/985302013_850215.html

${ }^{7}$ http://elpais.com/diario/2002/11/14/espana/1037228414_850215.html

${ }^{8} \mathrm{http}: / /$ elpais.com/diario/2006/09/08/espana/1157666416_850215.html, http://www.abc.es/hemeroteca/historico04-12-2006/abc/Internacional/la-ue-exigira-visado-a-los-bolivianos-a-partir-del-uno-de-abril-de2007_153293158161.html
} 
Table 1: Bolivian Immigration to Europe

\begin{tabular}{|c|c|c|c|c|c|c|c|c|c|c|}
\hline Country & 2002 & 2003 & 2004 & 2005 & 2006 & 2007 & 2008 & 2009 & 2010 & 2011 \\
\hline Austria & 26 & 35 & 37 & 33 & 26 & 16 & 15 & & & \\
\hline Belgium & & & & & & & & & 78 & 94 \\
\hline Bulgaria & & & & & & 0 & 0 & & & \\
\hline Cyprus & 0 & 0 & 0 & 0 & 0 & 0 & 0 & & & \\
\hline Czech Republic & 9 & 6 & 9 & 11 & 11 & 19 & 9 & 5 & 1 & 2 \\
\hline Denmark & 35 & 25 & 32 & 25 & 15 & 18 & 8 & 13 & 5 & 11 \\
\hline Estonia & & & 0 & 0 & 1 & 0 & 0 & 0 & 0 & 0 \\
\hline Finland & 28 & 4 & 9 & 3 & 6 & 3 & 5 & 6 & 8 & 6 \\
\hline Germany & 0 & 322 & 334 & 334 & 352 & 330 & 284 & & & \\
\hline Greece & & & & & 2 & 0 & & & & \\
\hline Hungary & 1 & 2 & 0 & 1 & 3 & 1 & 8 & 2 & & \\
\hline Ireland & & & & & & & 3 & 1 & 1 & 17 \\
\hline Italy & 150 & 1071 & 1363 & 738 & 625 & 842 & 1143 & 1625 & 3362 & 1670 \\
\hline Latvia & 0 & 0 & 0 & 0 & 0 & 0 & 0 & 0 & 0 & \\
\hline Lithuania & 1 & 0 & 1 & 2 & 1 & 1 & 0 & 0 & 0 & 0 \\
\hline Luxembourg & 2 & 1 & 1 & 4 & 2 & 5 & 1 & 0 & 2 & 3 \\
\hline Malta & & & & & & 0 & & & & \\
\hline Netherlands & 43 & 51 & 47 & 29 & 59 & 50 & 54 & 47 & & \\
\hline Poland & & & & & 1 & 1 & 7 & & & \\
\hline Slovakia & 1 & 1 & 3 & 1 & 3 & 1 & 1 & 3 & 0 & 2 \\
\hline Slovenia & 2 & 0 & 0 & 0 & 0 & 1 & 0 & 1 & 1 & 1 \\
\hline Spain & 10625 & 24433 & 44049 & 44985 & 77755 & 51797 & 14120 & 9484 & 8692 & 8982 \\
\hline Sweden & 94 & 92 & 94 & 78 & 215 & 186 & 205 & 282 & 320 & 284 \\
\hline United Kingdom & 0 & 0 & 57 & 45 & & & & & & \\
\hline
\end{tabular}

Source: Eurostat

Note: This chart shows the flow of Bolivian immigrants per year for most EU countries as reported by the Statistical Office of the European Union. Only Spain has received a considerable number of Bolivian immigrants between 2002 and 2011.

and historical links but weak to the rest of the Schengen space. Since Spain, as explained in the next section, will be excluded from the estimation sample, Table 1 and 2 suggests that the effect of visas on trade is not conveyed trough changes in the stock of migrants.

In addition, migration is often a controversial subject in Europe. Figure 7 shows the number of press articles on the introduction of visas for Ecuadorian and Bolivian nationals in the major European newspapers. The figure shows that there were 28 articles on the introduction of visas for Ecuadorian nationals in the three major Spanish newspapers and none in other major European newspapers. The evidence is similar for the introduction of visas for Bolivian nationals. There were 38 single press papers in the three major Spanish newspapers and only 4 in other European dailies (one in the French Liberation, and three in the Italian La Reppublica). Moreover, the three articles published in the Italian daily narrate the journey of 82 Bolivian nationals who embarked on the Italian MSC Sinfonia cruise ship in Genoa to reach Spain. The interest of the article for Italian readers seems to reside therefore in the Italian ownership of the cruise ship and the Italian origin of the journey rather than in the introduction of visa requirements for Bolivian citizens. 
Table 2: Ecuadorian Immigration to Europe

\begin{tabular}{|c|c|c|c|c|c|c|c|c|c|c|}
\hline Country & 2002 & 2003 & 2004 & 2005 & 2006 & 2007 & 2008 & 2009 & 2010 & 2011 \\
\hline Austria & 77 & 89 & 58 & 48 & 36 & 33 & 35 & & & \\
\hline Belgium & & & & & & 410 & & & 472 & 847 \\
\hline Bulgaria & & & & & & 0 & 0 & & & \\
\hline Cyprus & 0 & 0 & 0 & 0 & 0 & 0 & 0 & & & \\
\hline Czech Republic & 8 & 17 & 11 & 19 & 17 & 12 & 10 & 8 & 2 & 9 \\
\hline Denmark & 30 & 22 & 22 & 25 & 21 & 15 & 19 & 20 & 21 & 12 \\
\hline Estonia & & & 0 & 0 & 0 & 1 & 0 & 1 & 0 & 0 \\
\hline $\begin{array}{l}\text { Finland } \\
\text { France }\end{array}$ & 3 & 7 & 7 & 13 & 13 & 8 & 11 & 21 & 13 & 14 \\
\hline Germany & 0 & 894 & 653 & 665 & 580 & 580 & 578 & & & \\
\hline Greece & & & & & 9 & 4 & & & & \\
\hline Hungary & 3 & 5 & 12 & 7 & 4 & 8 & 11 & 2 & & \\
\hline Ireland & & & & & & & 3 & 1 & 1 & 6 \\
\hline Italy & 2531 & 17870 & 18135 & 8278 & 6047 & 4414 & 6874 & 6324 & 6168 & 4164 \\
\hline Latvia & 0 & 0 & 0 & 0 & 0 & 0 & 0 & 0 & 0 & \\
\hline Lithuania & 0 & 0 & 2 & 0 & 2 & 0 & 2 & 2 & 0 & 0 \\
\hline Luxembourg & 5 & 13 & 9 & 2 & 4 & 16 & 4 & 6 & 13 & 5 \\
\hline Malta & & & & & & 0 & & & & \\
\hline Netherlands & 140 & 138 & 126 & 129 & 121 & 119 & 128 & 97 & & \\
\hline Poland & & & & & 4 & 2 & 5 & & & \\
\hline Slovakia & 0 & 1 & 6 & 1 & 2 & 6 & 6 & 17 & 12 & 1 \\
\hline Slovenia & 2 & 4 & 0 & 0 & 0 & 1 & 1 & 5 & 1 & 0 \\
\hline Spain & 88967 & 99380 & 17202 & 15234 & 21387 & 30162 & 37752 & 18212 & 14599 & 11947 \\
\hline Sweden & 109 & 105 & 84 & 94 & 202 & 145 & 106 & 97 & 112 & 90 \\
\hline United Kingdom & 0 & 751 & 0 & 136 & & & & & & \\
\hline
\end{tabular}

Source: Eurostat

Note: This chart shows the flow of immigrants from Ecuador per year for most EU countries as reported by the Statistical Office of the European Union. Only Spain received a considerable number of Ecuadorian immigrants between 2002 and 2011. 
Figure 7: Mentions of the introduction of Visas for Bolivian and Ecuadorian Citizens in major newspapers

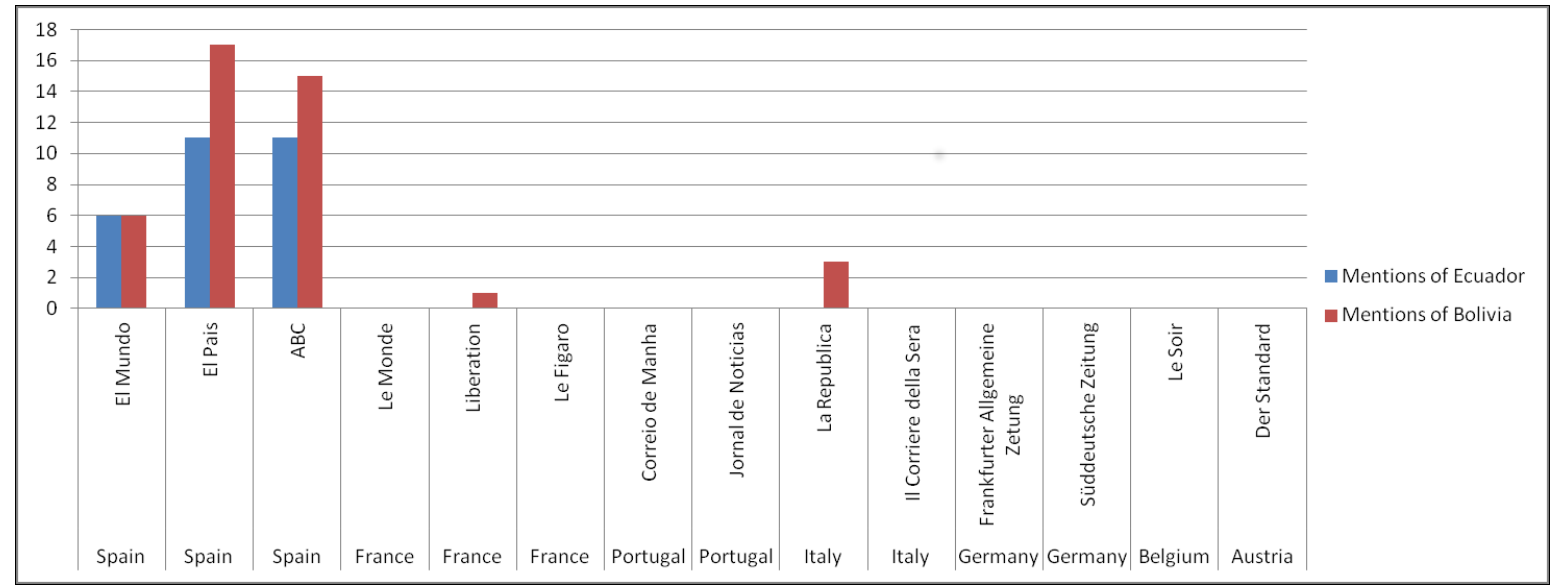

Source: Major European Newspapers archives. Author's own calculations.

Note: This chart reports the number of times the introduction of short-stay visas by Schengen members for Ecuadorian or Bolivian nationals was mentioned in a newspaper article in printed or online versions. The introduction of visa measures for these two countries nationals featured in a large number of press releases in Spain (28 and 38 single press articles for Ecuador and Bolivia respectively). There were no mentions of the introduction of introduction of short stay visas for Ecuadorian nationals in any major EU newspaper outside Spain. There were only four mentions in single press articles of the introduction of short-stay visas for Bolivian nationals outside Spain.

The introduction of visa requirements by a Schengen country, having no former intentions to introduce a visa, but pushed by the requests of a Schengen partner, Spain in this case, to shift a third country to the negative list can thus be seen as an external shock. Using this fact in order to avoid endogeneity problems, we estimate the causal impact of visa restrictions on bilateral trade flows in goods.

\section{Empirical strategy}

The dominating strategy when taking advantage of natural experiments is to follow a differencein-differences strategy ${ }^{9}$. In the international trade literature however, estimations of the gravity equation have become the dominating empirical approach. It has indeed been shown that several theoretical models of international trade, and among them the Melitz-Chaney model, yield gravity equations. Moreover, the question of how to correctly estimate gravity equations is at the center of a very large, and growing, body of research. For these two reasons that I will briefly develop below, the empirical strategy of this paper is based on the estimation of different gravity equations. Meanwhile, most of the results presented below are accompanied by annexes pre-

\footnotetext{
${ }^{9}$ The difference-in-differences technique compares the effect of a given policy on defined control and treatment groups. In practice it amounts to comparing changes in averages between these two groups.
} 
senting the results of similar estimations following a difference-in-difference strategy ${ }^{10}$. Starting from the first estimations of the gravity equation in Tinbergen (1962), the tool became the most widely used empirical method in international trade. However, despite its empirical success, the lack of theoretical foundations was seen as a major drawback by many trade economists. Anderson (1979) was the first to show that the gravity equation could be derived from a theoretical model. As other theoretical models followed, and in particular Eaton and Kortum (2002) and Anderson and van Wincoop (2003), it became apparent that the gravity equation could be obtained from a large class of models. Moreover most models with heterogeneous firms also yield gravity equations [Melitz and Ottaviano (2008), Chaney (2008)].

These theoretical foundations of the gravity equation had major implications in the estimation of gravity equations. It became apparent that multilateral resistance terms had to be accounted for [Anderson and van Wincoop (2003)] and that many of the previous estimations of the gravity equation where thus biased or theoretically inconsistent [Baldwin and Taglioni (2006)]. Multilateral resistance terms absorb a number of observable and unobservable characteristics of trade partners. Not accounting for the latter leads therefore a omitted variable bias.

An additional problem in most estimations of the gravity equation is highlighted in Santos Silva and Tenreyro (2006) and Westerlund and Wilhelmsson (2009). The bias these two papers point to is of particular importance in samples containing a large number of zeroes. In such cases using ordinary least squares to estimate a log-linearized gravity equation implies dropping al zeroes that account for a considerable share of the data. Dropping this share of the data can heavily bias the estimations as zero trade flows are not randomly distributed and their incidence is highly correlated with distance. Additionally, Santos Silva and Tenreyro (2006) also point out that estimations of the log-linearized gravity equation are unbiased only under the assumption that the error term is statistically independent from the regressors. Homoscedasticity is however often violated by the data samples used to estimate gravity equations.

The empirical strategy implemented here takes advantage of a natural experiment to circumvent these pitfalls. First, in order to indentify a causal link between the introduction of a visa and its impact on bilateral flows of goods we take advantage of the exogeneity of visas between Ecuador and Bolivia and members of the Schengen space other than Spain. Therefore, I exclude from the estimation trade flows between Ecuador and Spain or Bolivia and Spain to solve from the bias arising from reverser causation. Second, to in order to avoid the omitted variable bias stemming from the unobservable multilateral resistance terms most of the specifications presented below include a combination of year, pair and country fixed effects. Finally, following Santos Silva and Tenreyro (2006), we use in our preferred estimation method the Poisson Pseudo-Maximum Likelihood estimator (PPML). Other than allowing to include zero trade flows, the estimations using PPML are robust to several common patterns of heteroskedascity arising in gravity-like settings. While incidental parameter bias is not a problem in OLS, its

\footnotetext{
${ }^{10}$ For the reasons described, the difference-in-difference specification is not our preferred estimation strategy. However, it is in line with the literature using natural experiments. More importantly, this specification allows us to perform the analysis at the 2 and 6 digits level of the HS system. Estimating a theory-consistent gravity equation at the 6 digit level of the HS system would, with the required fixed effects, not be feasible with the computational capacity available to us. Additionally, if one uses the PPML Poisson estimator, as we do in the next section, the extremely large number of fixed effects which need to be included will trigger an incidental parameter bias. We are not aware of any research aiming at evaluating the magnitude of such bias.
} 
implications for PPML are still unclear. Charbonneau (2012) shows that with $N=T=2$ the PPML estimator suffers from the incidental parameter bias in a setting with two fixed effects. However, Fernández-Val and Weidner (2013) prove that in panels with large $\mathrm{N}$ and large $\mathrm{T}$, there is no incidental parameter bias when the regressors are strictly exogenous. Similarly, Jochmans (2015) proposes a strategy to construct Generalized Method of Moments estimators that completely eliminate incidental parameter bias with two fixed effects.

Figure 8: Average imports from Schengen Dests.

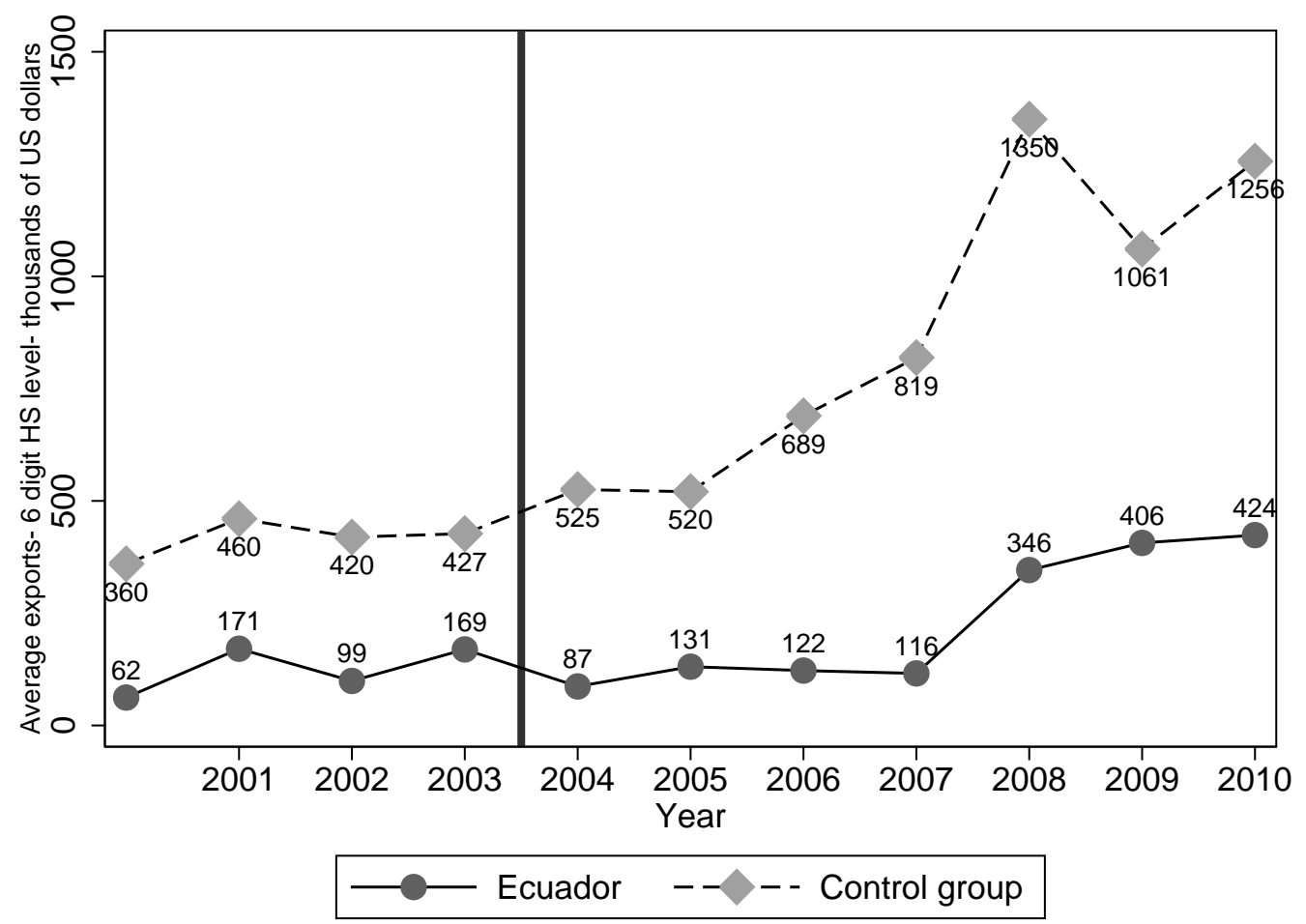

Source: BACI CEPII

Note: This graph plots the average imports at 6 digits of the Harmonized System per year by all the Schengen members originating in Ecuador or in the countries of the control group. Figures are reported in thousands of current US dollars. While there is a difference in levels, there does not seem to be any differences in the trends between Ecuador and countries in the control group. 
Figure 9: Average imports from Schengen Dests.

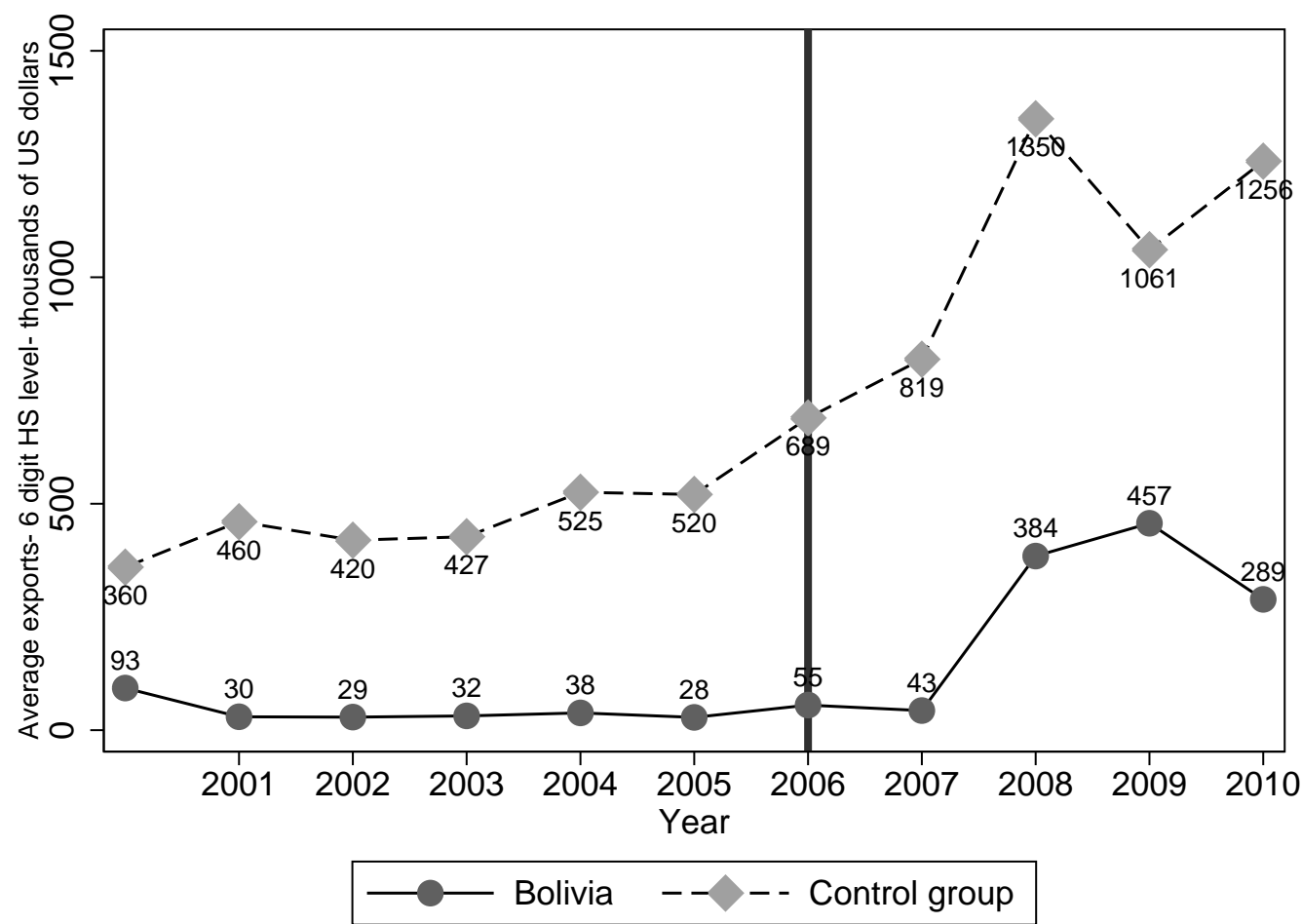

Source: BACI CEPII

Note: This graph plots the average imports at 6 digits of the Harmonized System per year by all the Schengen members originating in Bolivia or in the countries of the control group. Figures are reported in thousands of current US dollars. While there is a difference in levels, there does not seem to be any differences in the trends between Bolivia and countries in the control group.

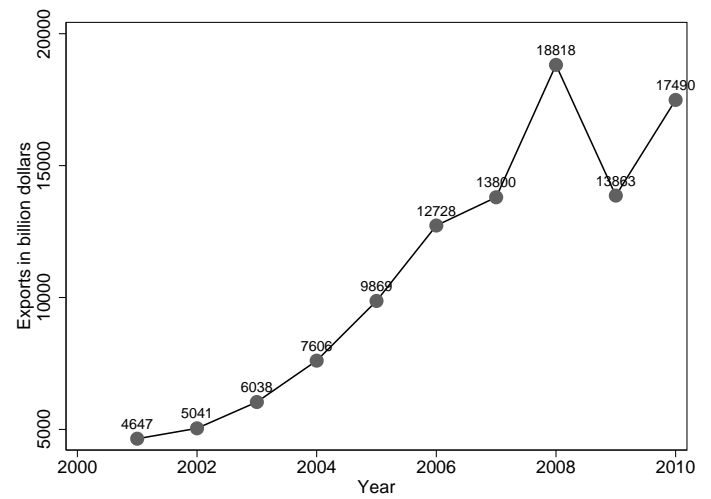

Figure 10: Total Exports of Ecuador

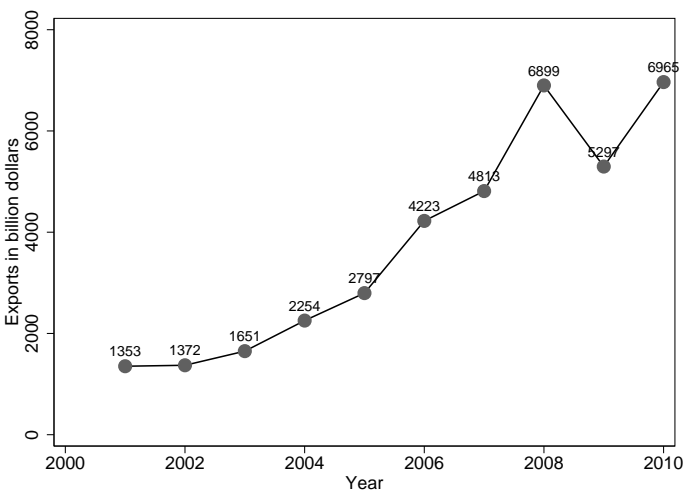

Figure 11: Total Exports of Bolivia

Note: Figure 10 plots total exports of Ecuador in millions of current US dollars. Figure 11 plots total exports of Bolivia in millions of current US dollars. It can be noticed that the total exports of Ecuador and Bolivia do not fall after the introduction of short-stay visas by Schengen Members. 
The evidence presented here indicates that there are no differences in the trend between the treated group and the control group. Figures 8 and 9 present the average imports from Schengen destinations for the control group and Ecuador and Bolivia respectively. The graphic evidence (and also the results from the difference-in-differences estimation with covariates presented in appendix B) supports the hypothesis of a common trend before the introduction of a visa. Figures 10 and 11 plot Ecuador's and Bolivia's total exports respectively. I can be observed from the graph that the total exports of these two countries are continuously increasing during all the years of the sample with the exception 2009. More importantly, total exports are increasing, in both cases, in the years following the introduction of visas to enter the Schengen Space.

Figure 12: Residuals from a gravity equation with pair fixed effects Ecuador vs. Control group

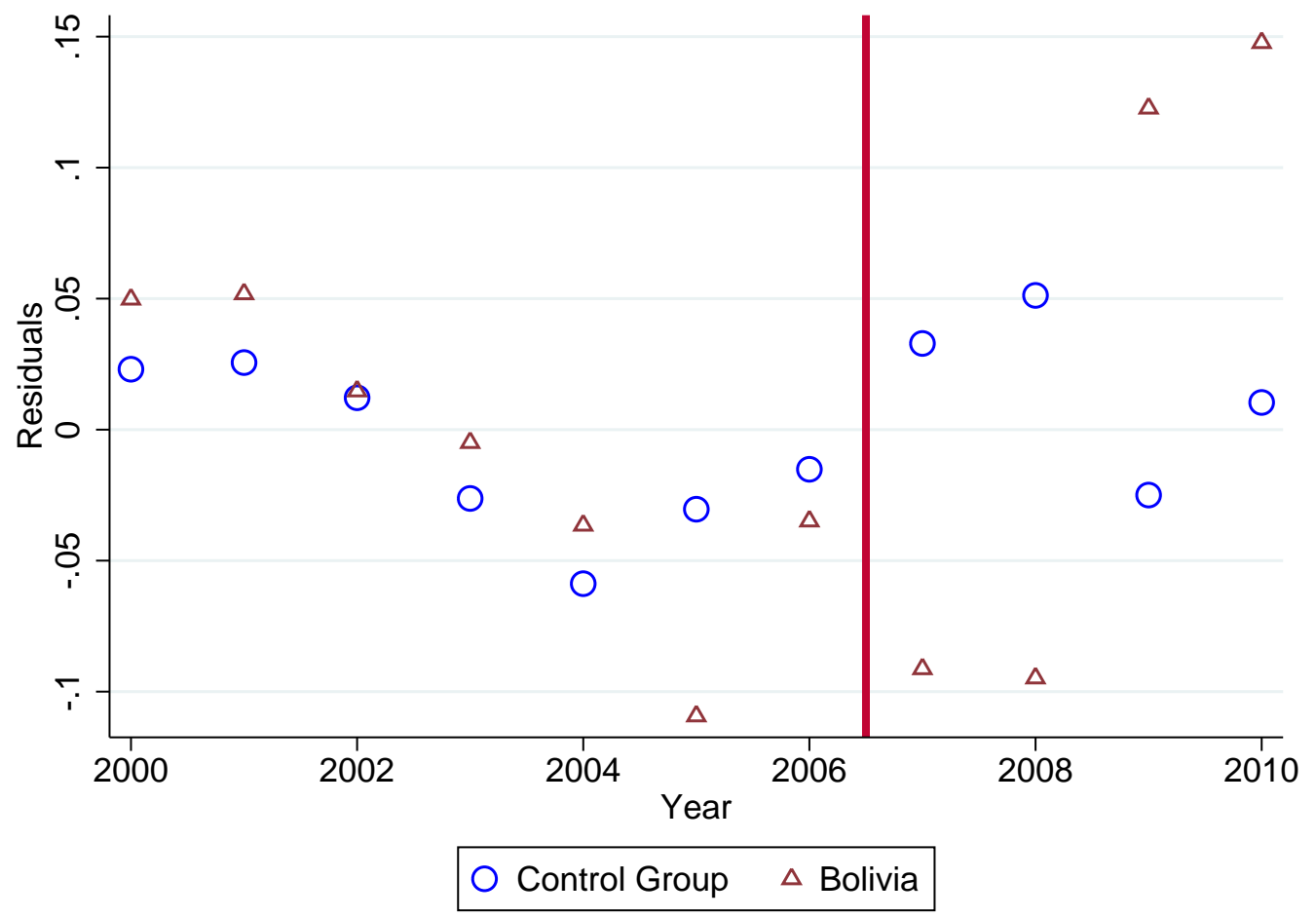

Note: This graph plots the residuals of a gravity equation estimated including GDPs per capita and populations of both the importer and exporter country, common currency and FTA dummies and year and pair fixed effects. The horizontal line shows the year of introduction of visas.

Figures 12 and 13 plot the residuals from the estimation of a gravity equation including variables commonly used in the gravity literature (population, GDP per capita, common currency and RTAs) and pair fixed effects. In both figures the residuals for the control group are above the residuals for Ecuador and Bolivia in most of the years following the introduction of a visa. In both cases, there is no discernible pattern in the years before the introduction of visas. 
Figure 13: Residuals from a gravity equation with pair fixed effects Bolivia vs. Control group

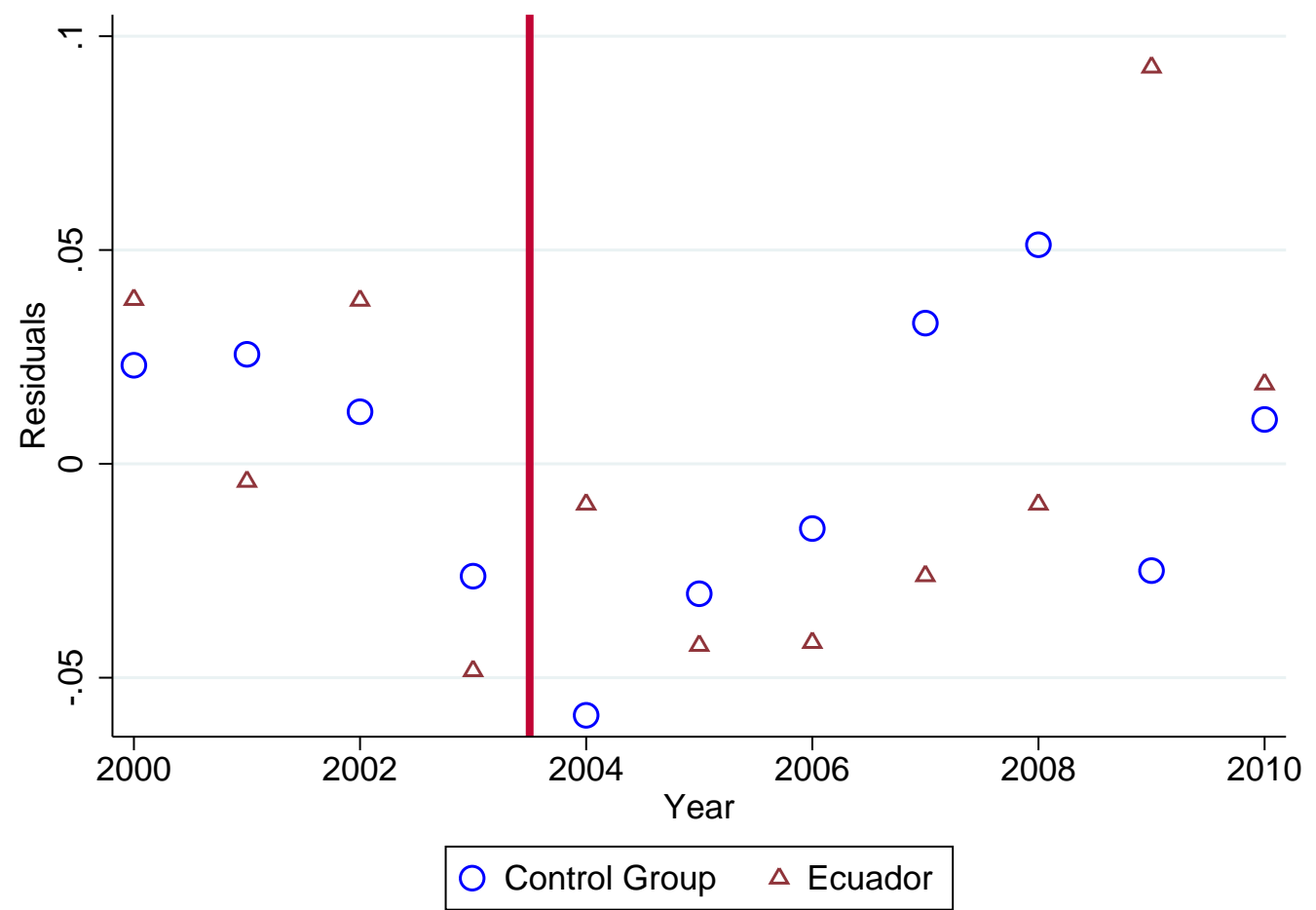

Note: This graph plots the residuals of a gravity equation estimated including GDPs per capita and populations of both the importer and exporter country, common currency and FTA dummies and year and pair fixed effects. The horizontal line shows the year of introduction of visas.

We begin by estimating the following gravity equation:

$$
\begin{aligned}
E\left(\text { imports }_{j, i, t} / x_{j, i, t}\right)=\operatorname{Exp}\left[\beta_{0}+\beta_{1} \cdot \operatorname{LnGDPcap}_{i, t}+\beta_{2} \cdot \operatorname{LnPop}_{i, t}\right. \\
\\
\left.+\beta_{3} \cdot \operatorname{LnGDPcap}_{j, t}+\beta_{4} \cdot \operatorname{LnPop}_{j, t}+\beta_{5} \cdot \operatorname{visa}_{i, j, t}\right]
\end{aligned}
$$

where imports $_{i, j, t}$ are the bilateral imports from $j$ to $i$ in period $t, v i s a_{i, j, t}$ is a dummy variable equal to 1 when the visa restrictions are in place and to zero otherwise. LnGDPcap $i, t$ and $L n P o p_{i, t}$ are the logs of the per capita income and of the population of the exporter country. Similarly, $L n G D P c a p_{j, t}$ and $L n P o p_{j, t}$ are the logs of the per capita income and of the population of the importer country.

Equation 2 is estimated using the Poisson Pseudo Maximum Likelihood estimator. The estimator allows obtaining consistent estimators in the presence of heteroskedasticity which arises due to the log linearization of the gravity equation [Santos Silva and Tenreyro (2006)]. In addition, it allows us to include zero trade flows in the estimation which would have otherwise been dropped when the gravity equation is log-linerealized. 
Table 3: Gravity Regression Results

\begin{tabular}{|c|c|c|c|c|c|}
\hline VARIABLES & $\begin{array}{c}\text { (1) } \\
\text { Naive } \\
\text { tradevalue }\end{array}$ & $\begin{array}{c}\text { (2) } \\
\text { Year FE } \\
\text { tradevalue }\end{array}$ & $\begin{array}{c}\text { (3) } \\
\text { Dyad FE } \\
\text { \& Year FE } \\
\text { tradevalue }\end{array}$ & $\begin{array}{c}(4) \\
\text { Exp } \backslash \text { Imp FE } \\
\text { \& Year FE } \\
\text { tradevalue }\end{array}$ & $\begin{array}{c}\text { (5) } \\
\text { Dyad FE } \\
\text { \& Year FE HS6 } \\
\text { tradevalue }\end{array}$ \\
\hline In GDP/Pop, origin & $\begin{array}{c}0.711^{\star * \star} \\
(0.0465)\end{array}$ & $\begin{array}{c}0.795^{\star \star \star} \\
(0.0663)\end{array}$ & $\begin{array}{c}0.770^{\star * \star} \\
(0.0802)\end{array}$ & $\begin{array}{c}0.657^{* * *} \\
(0.0446)\end{array}$ & $\begin{array}{c}0.443^{\star * *} \\
(0.0001)\end{array}$ \\
\hline In GDP/Pop, dest. & $\begin{array}{c}0.707^{\star \star \star} \\
(0.0455)\end{array}$ & $\begin{array}{c}0.791^{\star * *} \\
(0.0657)\end{array}$ & $\begin{array}{c}0.763^{\star \star \star} \\
(0.0787)\end{array}$ & $\begin{array}{c}0.678^{* * *} \\
(0.0401)\end{array}$ & $\begin{array}{c}0.508^{* * *} \\
(0.0001)\end{array}$ \\
\hline In Pop, origin & $\begin{array}{c}0.812^{* * *} \\
(0.0330)\end{array}$ & $\begin{array}{c}0.799^{* * *} \\
(0.0336)\end{array}$ & $\begin{array}{c}0.805^{\star * *} \\
(0.0369)\end{array}$ & $\begin{array}{c}-1.193^{\star * *} \\
(0.244)\end{array}$ & $\begin{array}{c}1.041^{\star * *} \\
(0.001)\end{array}$ \\
\hline In Pop, dest. & $\begin{array}{c}0.849^{* * *} \\
(0.0314)\end{array}$ & $\begin{array}{c}0.836^{* * *} \\
(0.0314)\end{array}$ & $\begin{array}{c}0.844^{* * *} \\
(0.0338)\end{array}$ & $\begin{array}{c}-0.800^{\star *} \\
(0.356)\end{array}$ & $0.911^{* * *}$ \\
\hline In dist & $\begin{array}{c}-0.861^{* * *} \\
(0.0624)\end{array}$ & $\begin{array}{c}-0.832^{* * *} \\
(0.0659)\end{array}$ & & $\begin{array}{c}-1.040^{* * *} \\
(0.0830)\end{array}$ & \\
\hline Visa & $\begin{array}{c}-0.687^{\star * \star} \\
(0.212)\end{array}$ & $\begin{array}{c}-0.483^{\star \star} \\
(0.228)\end{array}$ & $\begin{array}{l}-0.415 \\
(0.259)\end{array}$ & $\begin{array}{c}-0.832^{\star \star \star} \\
(0.301)\end{array}$ & $\begin{array}{c}-0.222^{\star \star \star} \\
(0.0009)\end{array}$ \\
\hline Both in EU & $\begin{array}{l}-0.130 \\
(0.122)\end{array}$ & $\begin{array}{c}-0.0708 \\
(0.126)\end{array}$ & $\begin{array}{c}-0.0763 \\
(0.131)\end{array}$ & $\begin{array}{c}0.0945^{* * *} \\
(0.0343)\end{array}$ & \\
\hline Constant & $\begin{array}{c}-14.05^{\star \star \star} \\
(1.158)\end{array}$ & $\begin{array}{c}-15.68^{* * *} \\
(1.480)\end{array}$ & $\begin{array}{c}-15.35^{\star * *} \\
(1.691)\end{array}$ & $\begin{array}{c}49.63^{\star * *} \\
(8.227)\end{array}$ & \\
\hline Observations & 11,194 & 11,194 & 11,194 & 11,194 & $3,428,250$ \\
\hline
\end{tabular}

Note: Standard errors in parentheses with ${ }^{*},{ }^{* *}$ and ${ }^{* * *}$ respectively denoting significance at the $1 \%, 5 \%$ and $10 \%$ levels. Standard errors are clustered at the country pair level in all columns with the exception of column 5. In column 5 the large number of observations and fixed effects makes the calculation of the covariance matrix extremely difficult. Standard errors are not clustered in column 5.

Table 3 presents the results of the PPML estimation. The first column corresponds to the estimation of the gravity equation without taking into account the impact of multilateral resistance terms. The second column includes only yearly fixed effects while the third column includes country pair fixed effects and year fixed effects. The fourth column, our preferred specification, includes exporter and importer fixed effects and yearly fixed effects. The results presented in this column control therefore for the unobserved multilateral resistance terms and also for the particular characteristics of a given year. Finally, column (5) includes pair and year fixed effects as column (3) but is estimated at the 6 digit level of the Harmonized system. In columns (1) to (4) standard errors are clustered by country-pair. In column (5) the large number of observations and fixed effects makes the calculation of the covariance matrix extremely difficult and 
estimations rarely converge. Standard errors are therefore not clustered in this last specification.

The results of column (1) are in line with those usually found in the gravity equation literature. The GDP per capita as the population of both the importer and exporter countries have positive and statistically significant close to 1 coefficients. Distance has a negative impact close to -1 . The coefficient associated with the existence of a visa has the expected sign and is statistically significant at the $1 \%$ level. Column (2) presents similar results. The coefficient associated with the visa dummy is negative and statistically significant at the $10 \%$ level. In column 3 the coefficient associated with the visa dummy is negative but significant only at the $15 \%$ level. Column 4, which summarizes the results of our preferred specification, shows that the coefficient associated with the visa dummy is negative and statistically significant at the $1 \%$ level. Finally, in column (5), the visa is also negative and significant at the $1 \%$ level.

This first set of results show a large causal impact of visas. The introduction of a visa has a negative and statistically significant in all the tested specifications of the gravity equation. In our preferred specification, which includes exporter and importer and year fixed effects, the introduction of visa reduces bilateral trade by $43,5 \%$. Moreover, appendix A shows the results of a similar exercise but including also within the estimation Colombia and Peru which needed visas at the beginning of the estimated period. The visas where introduced for similar reasons as in the case of Ecuador and Bolivia. However these visas where put in place before the adoption of a negative and positive country list. The results of this estimation are very similar to the ones presented in Table 3. Again our preferred specification shows a reduction of bilateral trade flows of around $40 \%$.

Appendix B shows the results from following an atheoretical difference-in-differences approach. While the very large theoretical and empirical corpus speaks in favor of the gravity equation, we present these results as robustness checks. This strategy is also more in line with the traditional approach in the empirical literature exploiting natural experiments and allows for differences between the treated and non-treated groups. Appendix $\mathrm{C}$ shows the estimation of the following equation:

$$
\text { imports }_{i, j, t}=\beta_{0}+\beta_{1} \cdot \text { period }_{t}+\beta_{2} \cdot \text { visa }_{i, j}+\beta_{3} \cdot \operatorname{period}_{t} \cdot \operatorname{visa}_{i, j}+x_{i, j, t}+e_{i, j, t}
$$

where imports $_{i, j, t}$ are the bilateral imports at the two digit level of the Harmonized System from $j$ to $i$ in period $t$, period $i$ is a dummy variable equal to 1 once the visa restriction is in place and to zero otherwise, visa is equal to 1 if a visa is required to travel between the origin and destination countries ${ }^{11}$. Trade data comes from Gaulier and Zignago (2010).

In order to rule out the possibility that the results are being driven by differences in the two groups, we also estimate the previous equation but including the most common determinants of bilateral trade flows used in gravity equations, $x_{i, j, t}$. GDP_exp and Pop_exp are the per capita

\footnotetext{
${ }^{11}$ One could argue that the dummy variable cannot correctly handle heterogeneity in terms of the difficulty to obtain a visa for nationals of different countries. In order to take into account this possibility I use data on the percentage of visa refusals by the United States for nationals of each country. We do not have however a similar natural experiment for USA visa policy and data of this kind is to the best of our knowledge not available for Schengen Space. The results for USA visa refusal rates are presented on appendix $\mathrm{C}$.
} 
and the population of the exporter country. GDP_imp and Pop_imp represent the same figures for the importer country. Results are presented in columns (2) and (4) of appendix B.

The control group is made up by 50 countries $^{12}$ which remained in the positive list from 2002 to 2009 plus the members of the European Union, which of course do not require visas to travel inside the Union.

Column (1) and (2) of appendix B present the results, for Ecuador and Bolivia, respectively, of the difference in difference estimation conducted in this manner. The introduction of a visa by the Schengen Area countries had for both Bolivia and Ecuador a statistically significant, at the $1 \%$, and considerable negative impact on trade flows. Columns 3 and 4 of Figure 12 indicate that once the covariates are added to the estimated equation, no residual differences persist between the two groups.

Finally, appendix D shows the result of a generalized difference-in-differences taking advantage of the multiple time periods and the difference in timing. We estimate therefore the following equation:

$$
\begin{aligned}
\text { imports }_{i, j, s, t}=\beta_{0}+\beta_{1} \cdot \text { period }_{t}+\beta_{2} \cdot v_{i s a_{i}} & +\beta_{3} D_{i, j, t}+\beta_{4} \cdot G D P_{\text {exp }} \\
& +\beta_{5} \cdot \text { Pop }_{\text {exp }}+\beta_{6} G D P_{i m p}+\beta_{7} \cdot \text { Pop }_{i m p}+\epsilon_{i, j, t}
\end{aligned}
$$

The results presented in the appendix confirm thus the negative impact of visas on bilateral trade flows.

\section{Which products?}

Which products should be more affected by the introduction of a visa? As discussed previously, if visas act as fixed trade costs, then in an Melitz-Chaney setting, differentiated goods should be more affected by the introduction of a visa than homogeneous goods. Moreover, a share of the impact of visas is most likely conveyed trough network effects. If the imposition of a visa increases the cost of face-to-face contacts then we would expect the impact to be larger for differentiated products than for homogenous products.

In order to answer this question we use the classification proposed in Rauch (1999). Rauch classifies products using the Standard International Trade Classification (SITC). Products are divided into three categories: organized exchange, reference priced, and differentiated commodities. Organized exchange and referenced price are similar categories. While organized exchange groups all commodities for which there is some sort of centralized market that fixes the price, referenced priced groups products for which there is not an organized exchange but

\footnotetext{
${ }^{12}$ Argentina, Australia, Austria, Brazil, Brunei Darussalam, Bulgaria, Canada, Chile, Costa Rica, Croatia, Cyprus, Czech Republic, Denmark, El Salvador, Estonia, Finland, France, Germany, Greece, Guatemala, Honduras, Hungary, Ireland, Israel, Italy, Japan, Korea, Rep., Latvia, Lithuania, Malaysia, Malta, Mexico, Netherlands, New Zealand, Nicaragua, Paraguay, Poland, Portugal, Romania, San Marino, Singapore, Slovak Republic, Slovenia, Spain, Sweden, Switzerland, United Kingdom, United States, Uruguay, Venezuela
} 
for which reference prices are listed in trade publications. Products that are not classified under referenced priced and organized exchange categories are considered to be differentiated products.

Table 4: Homogeneous vs. Differentiated products

\begin{tabular}{|c|c|c|c|c|}
\hline VARIABLES & $\begin{array}{c}(1) \\
\text { Homogeneous } \\
\text { Ecuador }\end{array}$ & $\begin{array}{c}\text { (2) } \\
\text { Differentiated } \\
\text { Ecuador }\end{array}$ & $\begin{array}{c}(3) \\
\text { Homogeneous } \\
\text { Bolivia } \\
\end{array}$ & $\begin{array}{c}\text { (4) } \\
\text { Differentiated } \\
\text { Bolivia } \\
\end{array}$ \\
\hline visa*time dummy & $\begin{array}{c}-1,069^{\star *} \\
(448.8)\end{array}$ & $\begin{array}{c}-2,344^{\star \star \star} \\
(252.8)\end{array}$ & $\begin{array}{c}-1,859^{* * *} \\
(229.7)\end{array}$ & $\begin{array}{c}-2,279^{\star * \star} \\
(238.9)\end{array}$ \\
\hline Time & $\begin{array}{c}-1,955^{\star * \star} \\
(503.2)\end{array}$ & $\begin{array}{c}-3,783^{* * *} \\
(471.5)\end{array}$ & $\begin{array}{c}-3,104^{\star * *} \\
(324.2)\end{array}$ & $\begin{array}{c}-4,445^{\star * *} \\
(513.6)\end{array}$ \\
\hline Visa & $\begin{array}{c}2,155^{\star \star \star} \\
(187.3)\end{array}$ & $\begin{array}{c}2,497^{\star \star \star} \\
(249.9)\end{array}$ & $\begin{array}{c}2,089^{\star * \star} \\
(188.5)\end{array}$ & $\begin{array}{c}2,349^{\star \star \star} \\
(237.9)\end{array}$ \\
\hline Constant & $\begin{array}{c}2,895^{\star * *} \\
(291.0)\end{array}$ & $\begin{array}{c}4,027^{* * *} \\
(469.8)\end{array}$ & $\begin{array}{c}3,328^{* * *} \\
(314.6)\end{array}$ & $\begin{array}{c}4,533^{* * *} \\
(513.5)\end{array}$ \\
\hline $\begin{array}{l}\text { Observations } \\
R^{2}\end{array}$ & $\begin{array}{c}878,196 \\
0.000\end{array}$ & $\begin{array}{c}2,160,502 \\
0.000\end{array}$ & $\begin{array}{c}805,504 \\
0.000\end{array}$ & $\begin{array}{c}1,875,388 \\
0.000\end{array}$ \\
\hline
\end{tabular}

Note: The estimation is performed on trade flows at the four digit level of the Standard Trade Classification. Standard errors in parentheses with ${ }^{*},{ }^{* *}$ and ${ }^{* * *}$ respectively denoting signifficance at the $1 \%, 5 \%$ and $10 \%$ levels. Time dummy is a dummy variable equal to one once a short-stay visa is introduced (i.e. 2003 for Ecuador and 2007 for Bolivia). Visa dummy is equal to one for trade flows between the Schengen members and Bolivia or Ecuador. Columns 1 and 3 present the results when the sample is restricted to products classified as "organized exchange" or "reference priced" in Rauch's product classification. Columns 2 and 4 present the results when only products of the "differentiated commodities" category are included in the sample.

In order to examine the impact of the implementation of a visa on the different categories we group together the referenced priced or organized exchange categories. The difference between these two categories does not seem relevant for the present exercise. We classify both categories as homogenous products. The remaining products are classified as differentiated products.

While our preferred specification is a gravity equation given the subdivision of products, estimating a gravity equation with the required fixed effects and using the PPML estimator raises a number of issues. First, the severity of the bias arising in this setting with such a large number of regressors has, to the best of our knowledge, not been yet examined. In addition, even reducing the sample, the colinearity problems triggered by the introduction of a large number of fixed effects makes calculating the covariance matrix and therefore clustering standard errors a computationally extremely challenging problem. For these reasons instead of estimating a gravity equation, we implement therefore the same difference-in-difference approach from appendix B using each category of products.

Columns (1) and (2) of Figure 4 present the results for Ecuador. The first column reports the results for the sample restricted to homogeneous products while the second presents the 
results for a sample limited to differentiated products. As expected, in both cases the effect is negative and statistically significant at the $1 \%$ level. More interestingly, treatment effect is almost two times larger for differentiated products than for homogeneous commodities.

Similarly, columns (3) and (4) of Figure 4 show the impact, for Bolivia, of the introduction of a visa for homogeneous and differentiated products respectively. Once again the treatment effect is negative and statistically significant at the $1 \%$ level. The treatment effect is larger for differentiated products than for homogeneous products.

\section{New Products}

According to the survey conducted by Oxford Economics, business trips appear to be especially important to gain new customers. In this section we study the impact on the introduction of a visa on the number of new products traded. Ideally one would use product-level data for this purpose. However bilateral trade data at the product level covering all the countries included in our sample is not readily available. Instead I use data provide by the BACI database developed by CEPII. BACI provides trade data at the 6 digit level of the Harmonized System.

In order to identify the export of a new product I proceed in the following way. Every time a new 6-digit product data line changes from 0 to a positive value from one year to the next I code this change as the export of a new product. This of course underestimates the number of new products (as new products might also be exported inside 6 digit codes). If the propensity to export a new product is equally impacted across 6 digit lines by the introduction of a visa our estimation should not be biased.

In order to examine this hypothesis we estimate the following equation:

$$
\begin{aligned}
\text { \# of new } \text { products }_{j, i, t}= & \beta_{0}+\beta_{1} \cdot \operatorname{LnGDPcap}_{i, t}+\beta_{2} \cdot \operatorname{LnPop}_{i, t}+\beta_{3} \cdot \operatorname{LnGDPcap}_{j, t} \\
& +\beta_{4} \cdot \operatorname{LnPop}_{j, t}+\beta_{5} \cdot \operatorname{visa}_{i, j, t}+e_{i, j, t}
\end{aligned}
$$

Table 5 summarizes the results from different estimations of equation 5 . The first column corresponds to the estimation of equation (5) without any fixed effects. The remaining specifications tested include a number of fixed effects to control for unobserved factors affecting the number of new products exported. The second column includes only yearly fixed effects while the third column includes country-pair fixed effects and year fixed effects. Finally the fourth column includes exporter and importer fixed effects and yearly fixed effects. In all the specifications the standard errors are robust and clustered by country-pair.

The impact of the introduction of a visa on the number of new exported products is negative, very large and statistically significant at the $1 \%$ level in the specifications presented in columns (1), (2) and (3). In column (4) the coefficient associated with the visa dummy is not statistically significant. Overall, the results support the hypothesis of a strong link between face-to-face contact and international trade. 
Table 5: Number of new exported products

\begin{tabular}{|c|c|c|c|c|}
\hline VARIABLES & $\begin{array}{c}\text { (1) } \\
\text { No FE } \\
\text { \# new products }\end{array}$ & $\begin{array}{c}\text { (2) } \\
\text { Year FE } \\
\text { \# new products }\end{array}$ & $\begin{array}{c}\text { (3) } \\
\text { Dyad FE } \\
\text { \& Year FE } \\
\text { \# new products }\end{array}$ & $\begin{array}{c}(4) \\
\text { Exp } \backslash \text { Imp FE } \\
\& \text { Year FE } \\
\text { \# new products }\end{array}$ \\
\hline In GDP/Pop, origin & $\begin{array}{c}0.339^{\star * *} \\
(0.0242)\end{array}$ & $\begin{array}{c}0.457^{\star * *} \\
(0.0311)\end{array}$ & $\begin{array}{c}0.482^{\star * \star} \\
(0.0315)\end{array}$ & $\begin{array}{l}0.0357 \\
(0.0248)\end{array}$ \\
\hline In GDP/Pop, dest. & $\begin{array}{c}0.120^{* * *} \\
(0.0191)\end{array}$ & $\begin{array}{c}0.224^{* * *} \\
(0.0260)\end{array}$ & $\begin{array}{c}0.249^{* * *} \\
(0.0295)\end{array}$ & $\begin{array}{c}0.113^{\star * *} \\
(0.0208)\end{array}$ \\
\hline In Pop, origin & $\begin{array}{c}0.247^{\star \star \star} \\
(0.0167)\end{array}$ & $\begin{array}{c}0.249^{\star \star \star} \\
(0.0176)\end{array}$ & $\begin{array}{c}0.236^{\star \star *} \\
(0.0196)\end{array}$ & $\begin{array}{l}0.203 \\
(0.149)\end{array}$ \\
\hline In Pop, dest. & $\begin{array}{c}0.159^{* * *} \\
(0.0161)\end{array}$ & $\begin{array}{c}0.162^{* * *} \\
(0.0164)\end{array}$ & $\begin{array}{c}0.149^{\star * *} \\
(0.0184)\end{array}$ & $\begin{array}{c}0.758^{\star \star *} \\
(0.129)\end{array}$ \\
\hline In dist & $\begin{array}{c}-0.284^{\star * *} \\
(0.0246)\end{array}$ & $\begin{array}{c}-0.289^{* * *} \\
(0.0240)\end{array}$ & $\begin{array}{c}-0.289^{* * *} \\
(0.0302)\end{array}$ & $\begin{array}{c}-0.382^{\star * *} \\
(0.0636)\end{array}$ \\
\hline Visa & $\begin{array}{c}-0.816^{\star * *} \\
(0.170)\end{array}$ & $\begin{array}{c}-0.521^{* * *} \\
(0.169)\end{array}$ & $\begin{array}{c}-0.459^{* *} \\
(0.230)\end{array}$ & $\begin{array}{l}0.391 \\
(0.269)\end{array}$ \\
\hline Observations & 7,354 & 7,354 & 7,354 & 7,354 \\
\hline
\end{tabular}

\section{Placebo tests}

In this section we perform a series of placebo tests to show the causality link between visas and trade. For this purpose I introduce false visa dummies, one in 2003 and one in 2007, between Schengen members and a number of third countries. Depending on the specification false visa dummies are introduced for Chile, Costa Rica, Malaysia and the Dominican Republic in 2003. Similarly, false visa dummies are introduced for Mexico, Japan, Argentina and Switzerland in 2007.

Figure 6 shows the result of estimating equation 2 using the PPML and pair and year fixed effects when introducing false visa dummies, one in 2003 and one in 2007 as described above, between Schengen members and a number of third countries. Reassuringly, the placebo visa coefficients are positive and have no statistically significant effect.

As a robustness test we perform a similar exercise, but estimating a difference-in-difference equation [equation 4]. I introduce again false visa dummies, one in 2003 and one in 2007 as described above, between Schengen members and a number of third countries. Table 11 of 
the appendix summarizes the results obtained. Again, in none of the placebo test performed with equation 4 , visas have a statistically significant effect on trade flows.

Table 6: Placebo test I: Falsified visas (gravity equation)

\begin{tabular}{lcccc}
\hline & $(1)$ & $(2)$ & $(3)$ & $(4)$ \\
& CHL & CRI & MYS & DOM \\
VARIABLES & JPX & JPN & ARG & CHE \\
& Trade & Trade & Trade & Trade \\
\hline \multirow{2}{*}{ Visa } & 0.172 & 0.172 & 0.0151 & 0.0269 \\
& $(0.248)$ & $(0.248)$ & $(0.118)$ & $(0.143)$ \\
In GDP, origin & $0.438^{* * *}$ & $0.438^{* * *}$ & $0.443^{\star * *}$ & $0.443^{* * *}$ \\
& $(0.107)$ & $(0.107)$ & $(0.108)$ & $(0.107)$ \\
In Pop, origin & 0.575 & 0.575 & 0.588 & 0.592 \\
& $(0.759)$ & $(0.759)$ & $(0.759)$ & $(0.758)$ \\
In GDP, dest. & $0.507^{* * *}$ & $0.507^{* * *}$ & $0.507^{* * *}$ & $0.508^{* * *}$ \\
& $(0.118)$ & $(0.118)$ & $(0.118)$ & $(0.118)$ \\
In Pop, dest. & 0.400 & 0.400 & 0.404 & 0.406 \\
& $(0.835)$ & $(0.835)$ & $(0.834)$ & $(0.834)$ \\
Observations & $3,428,250$ & $3,428,250$ & $3,428,250$ & $3,428,250$ \\
Number of dyad_hs & 344,219 & 344,219 & 344,219 & 344,219 \\
\hline
\end{tabular}

Standard errors in parentheses with *, ${ }^{* *}$ and ${ }^{* * *}$ respectively denoting signifficance at the $1 \%, 5 \%$ and $10 \%$ levels. Standard errors are clustered at the country pair level in all colummns. The estimation is performed using Poisson's pseudo-maximum likelihood estimator (PPML). Standard errors are clustered by country pair. Columns' headers indicate which countries receive a placebo treatment. The first country replaces Ecuador (i.e. the visa dummy is equal to one starting in 2003) and the second country replaces Bolivia. In dist. is the distance between the exporter and importer countries in logs taken from CEPIl's GeoDist database. Pair fixed and year fixed effects are included in all the regressions of the table.

Finally, I also perform a placebo test by falsifying the dates at which the visas were introduced. For this purpose, I estimate equation 2 but setting the introduction of visas for Ecuador and Bolivia one, two and three years before the actual introduction. The results of these placebo tests are presented in table 7. The first line of the table indicates the fake year of introduction of visas for Ecuador while the second line indicates the fake year for Bolivia. In none of the three placebo tests performed in such manner the visa variable is statistically significant at $40 \%$. Moreover, in the very demanding placebo test where a false visa is introduced just one year before the real visa, the visa variable is not significant at the $70 \%$ level. 
Table 7: Placebo test II: Falsified introduction dates (gravity equation)

\begin{tabular}{lccc}
\hline & 2003 & 2004 & 2005 \\
VARIABLES & 2000 & 2001 & 2002 \\
& Trade & Trade & Trade \\
\hline \multirow{3}{*}{ Visa } & & & \\
& -0.208 & -0.102 & -0.0582 \\
In GDP, origin & $(0.258)$ & $(0.223)$ & $(0.164)$ \\
& $0.442^{\star * *}$ & $0.442^{\star * *}$ & $0.442^{\star * *}$ \\
In Pop, origin & $(0.107)$ & $(0.107)$ & $(0.107)$ \\
& 0.593 & 0.592 & 0.591 \\
In GDP, dest. & $(0.758)$ & $(0.758)$ & $(0.758)$ \\
& $0.508^{\star * *}$ & $0.508^{\star * *}$ & $0.508^{\star * *}$ \\
In Pop, dest. & $(0.118)$ & $(0.118)$ & $(0.118)$ \\
& 0.404 & 0.404 & 0.404 \\
Observations & $(0.834)$ & $(0.834)$ & $(0.834)$ \\
Number of dyad_hs & $3,428,250$ & $3,428,250$ & $3,428,250$ \\
& 344,219 & 344,219 & 344,219
\end{tabular}

Standard errors in parentheses with ${ }^{*},{ }^{* *}$ and ${ }^{* * *}$ respectively denoting signifficance at the $1 \%, 5 \%$ and $10 \%$ levels. Standard errors are clustered at the country pair level in all colummns. The estimation is performed using Poisson's pseudo-maximum likelihood estimator (PPML). Standard errors are clustered by country pair. Columns' headers indicate which countries receive a placebo treatment. The first country replaces Ecuador (i.e. the visa dummy is equal to one starting in 2003) and the second country replaces Bolivia. Ln dist. is the distance between the exporter and importer countries in logs taken from CEPII's GeoDist database. Pair fixed and year fixed effects are included in all the regressions of the table.

\section{General equilibrium and welfare analysis}

In this section we explore the general equilibrium and welfare impact of removing all visa requirements for short stay travel. In this sense, we take advantage of the procedure developed in Dekle, Eaton, and Kortum (2007). The method's robustness has indeed been recently proven by Arkolakis, Costinot, and Rodríguez-Clare (2012). One particularly interesting feature is that it allows for changes in income through changes in wages. The results obtained can thus be rightly considered as general equilibrium results. While in Dekle, Eaton, and Kortum (2007) the procedure is derived from a Ricardian model, the results can be extended to most models yielding a structural gravity equation.

In order to perform this general equilibrium welfare analysis we follow Dekle, Eaton, and Kortum (2008). In the paper, the authors reexpress Eaton and Kortum (2002) gravity-consistent model in term of changes. This has the advantage of considerably reducing data requirements. In particular, this eliminates the need to know the actual level of trade costs. Only the relative change in such costs is required. In our case the change simply corresponds to exponentiating the coefficient we have obtained for the visa dummy in our estimations. 
Another important feature is that two observable endogenous parameters of the model, trade shares and income, perfectly identify the two main endogenous unobservables: trade costs and multilateral resistance terms. In a nutshell, the method, which is the vein of "exact hat" algebra, consists on using observed data on income and the ratio of a country's expenditure devoted to the purchase of other countries' goods in order to solve for multilateral resistance terms (price indexes) [Head and Mayer (2013)].

If we assume that labor is the only source of income in the model and that there are constant markups (or profits), then in most models yielding a gravity equation, trade shares $\pi_{n i}$ can be expressed in the following way [ Arkolakis, Costinot, and Rodríguez-Clare (2012)]:

$$
\pi_{n i}=\frac{\chi_{n i} N_{i}\left(w_{i} \tau_{n i}\right)^{\epsilon}}{\sum_{l} \chi_{n l} N_{l}\left(w_{l} \tau_{n l}\right)^{\epsilon}}
$$

where $\chi_{n i}$ can be a particular parameter of some model yielding a gravity equation and $N_{i}$ the number of goods produced in country i. Similarly in the counterfactual world trade shares can be written as:

$$
\pi_{n i}^{\prime}=\frac{\chi_{n i} N_{i}^{\prime}\left(w_{i} \tau_{n i}\right)^{\epsilon}}{\sum_{l} \chi_{n l} N_{l}^{\prime}\left(w_{l} \tau_{n l}\right)^{\epsilon}}
$$

Assuming that the number of goods produced in i, $N_{i}$, is constant, and dividing the actual expenditure by counterfactual expenditure shares, as showed first in Dekle, Eaton, and Kortum (2007) and reexpressed in a more general way in Head and Mayer (2013), changes in the share of country $i$ in country's $n$ spending can be expressed as:

$$
\hat{\pi}_{n i}=\frac{\left(\hat{Y}_{i} \hat{\tau}_{n i}\right)^{\epsilon}}{\sum_{l} \pi_{n l}\left(\hat{Y}_{i} \hat{\tau}_{n i}\right)^{\epsilon}}
$$

where $\hat{Y}_{i}$ denotes changes in income of country $\mathrm{i}$ and $\hat{\tau}_{n i}$ changes in bilateral trade flows. Plugging equation (8) into the market clearing condition changes in income can be obtained. Since the model has a unique equilibrium as shown in Alvarez and Lucas Jr (2007), the counterfactual can be solved by an iterative procedure.

We apply this procedure to examine the result of removing all visa requirements for short stay travel for a large number of countries (175 countries). For this purpose I use the visas database constructed by Neumayer (2011) while the counterfactual, we use the coefficient for the visa dummy obtained in our preferred specification of the gravity equation of section 5 (i.e. -0.403). We set the value of the elasticity of substitution at -5.03 , which is the average value obtained in more than 100 papers reviewed by Head and Mayer (2013).

Table 8 shows the top ten countries by welfare gains. The second column of the table gives the welfare change under the no short-stay visa scenario. It is remarkable that the four top countries in welfare gains are sub-Saharan African countries. Also half of the top ten countries are from this same continent. Removing short-stay visas would increase welfare by nearly $9 \%$ 
and $8 \%$ in Congo and Equatorial Guinea respectively. For Malaysia, the country with the lowest gains in the top ten table, removing visas would increase welfare by $3.9 \%$.

Table 8: Highest welfare gains

\begin{tabular}{lc}
\hline Country & Welfare_ratio \\
\hline Congo & 1.0877697 \\
Equatorial Guinea & 1.0793886 \\
Angola & 1.0740885 \\
Mauritania & 1.0464589 \\
Suriname & 1.0459772 \\
Libya & 1.0455616 \\
Cambodia & 1.0448984 \\
Guyana & 1.0439541 \\
Vietnam & 1.0420039 \\
Vanuatu & 1.0402379 \\
Malaysia & 1.0385797 \\
\hline
\end{tabular}

Note: This table presents the general equilibrium welfare changes (New welfare/Old welfare) that would be triggered by removing short stay visas. Only the ten largest welfare changes are presented.

Table 8 suggests that welfare gains from removing short-stay visas are concentrated among developing countries. Table 9 shows average welfare gains for the different income categories of the World Bank. The highest average welfare increase, $1.9 \%$, would in fact be attained by Lower Middle Income countries. The lowest average welfare increase, less than $1 \%$, is for high income countries.

Table 9: Average welfare gains by income category

\begin{tabular}{lc}
\hline Income Category & Welfare Ratio \\
\hline LIC & 1.0100446 \\
LMIC & 1.0187722 \\
UMC & 1.0156307 \\
HIC & 1.0090962 \\
\hline
\end{tabular}

Note: This table presents average general equilibrium welfare changes (New welfare/Old welfare) by the World's Bank income categories. LIC: Lower income countries. LMIC: Lower middle income countries. UMC: Upper-middle income countries. HIC: High income countries. 


\section{Conclusions}

Although having being signaled by policy makers as a barrier to trade, the impact of visas on international trade in goods has received little attention. This paper uses a natural experiment provided by the Schengen Area in order to show that visas have a large negative impact on bilateral trade flows. In particular, I use the Schengen Area rules to establish the causal link between visas and trade. The introduction of a visa to enter the Schengen Space reduced bilateral trade flows between Ecuador and Bolivia and the members of the Schengen Area, other than Spain, which is excluded from the estimation sample. The large and negative results do not seem to depend on the method used. Both the theory-consistent gravity equation and the atheoretical differences-in-differences approach yield large negative and statistically significant results.

The paper also provides additional evidence in favor of the hypothesis of the importance of face to face contact in international trade. The effect of the introduction of a visa is indeed much larger for differentiated products than for homogeneous products both for Bolivia and Ecuador. Similarly, the results show that the introduction of visa negatively impacts the number of new products exported by the two countries to Schengen destinations. These two findings put together suggest that the introduction of visas might affect the diversification and complexification of exports of developing countries.

Results are also important for policy makers in that they show the importance of including visa facilitation schemes into FTAs and other economic agreements. Visas are the most asymmetric of trade barriers and according to our preferred specification their negative impact is very large. Moreover, the general equilibrium counterfactual carried out in this paper suggests that removing short-stay visas would increase welfare in the developing world by $1.5 \%$ on average. Some sub-Saharan countries would see a considerable increase of economic welfare of around $8 \%$. Countries will most likely not abolish short-stay visa requirements in the near future but facilitating visas for business purposes would certainly bring about some of these welfare gains. Further research could examine whether the extensive margin of trade is more affected than the intensive margin. 
Figure 14: Gravity Regression Results

\begin{tabular}{|c|c|c|c|c|}
\hline VARIABLES & $\begin{array}{c}\text { (1) } \\
\text { Naif } \\
\text { tradevalue }\end{array}$ & $\begin{array}{c}\text { (2) } \\
\text { Year FE } \\
\text { tradevalue }\end{array}$ & $\begin{array}{c}\text { (3) } \\
\text { Dyad FE } \\
\text { \& Year FE } \\
\text { tradevalue }\end{array}$ & $\begin{array}{c}(4) \\
\text { Exp } \backslash I m p F E \\
\& \text { Year FE } \\
\text { tradevalue }\end{array}$ \\
\hline In GDP/Pop, origin & $\begin{array}{c}0.716^{\star * *} \\
(0.0482)\end{array}$ & $\begin{array}{c}0.802^{\star * *} \\
(0.0676)\end{array}$ & $\begin{array}{c}0.780^{\star * *} \\
(0.0816)\end{array}$ & $\begin{array}{c}0.699^{* * *} \\
(0.0432)\end{array}$ \\
\hline In GDP/Pop, dest. & $\begin{array}{c}0.711^{\star * *} \\
(0.0490)\end{array}$ & $\begin{array}{c}0.798^{\star * *} \\
(0.0692)\end{array}$ & $\begin{array}{c}0.773^{\star \star \star} \\
(0.0830)\end{array}$ & $\begin{array}{c}0.720^{\star \star \star} \\
(0.0363)\end{array}$ \\
\hline In Pop, origin & $\begin{array}{c}0.805^{\star * *} \\
(0.0326)\end{array}$ & $\begin{array}{c}0.795^{\star * *} \\
(0.0331)\end{array}$ & $\begin{array}{c}0.801^{* * *} \\
(0.0363)\end{array}$ & $\begin{array}{c}-1.324^{* * *} \\
(0.236)\end{array}$ \\
\hline In Pop, dest. & $\begin{array}{c}0.843^{* * *} \\
(0.0326)\end{array}$ & $\begin{array}{c}0.832^{* * *} \\
(0.0324)\end{array}$ & $\begin{array}{c}0.839^{* * *} \\
(0.0350)\end{array}$ & $\begin{array}{c}-0.940^{* * *} \\
(0.330)\end{array}$ \\
\hline In dist & $\begin{array}{c}-0.817^{\star * *} \\
(0.0466)\end{array}$ & $\begin{array}{c}-0.807^{* * *} \\
(0.0473)\end{array}$ & $\begin{array}{c}-0.805^{\star * *} \\
(0.0524)\end{array}$ & $\begin{array}{c}-1.040^{* * *} \\
(0.0829)\end{array}$ \\
\hline Visa & $\begin{array}{c}-0.691^{\star * *} \\
(0.212)\end{array}$ & $\begin{array}{c}-0.475^{\star \star} \\
(0.230)\end{array}$ & $\begin{array}{l}-0.403 \\
(0.262)\end{array}$ & $\begin{array}{c}-0.889^{* \star *} \\
(0.292)\end{array}$ \\
\hline Constant & $\begin{array}{c}-14.33^{\star \star \star} \\
(1.207)\end{array}$ & $\begin{array}{c}-15.91^{\star \star \star} \\
(1.481)\end{array}$ & $\begin{array}{c}-15.64^{\star \star \star} \\
(1.678)\end{array}$ & $\begin{array}{c}53.40^{\star \star *} \\
(7.665)\end{array}$ \\
\hline Observations & 11,194 & 11,194 & 11,194 & 11,194 \\
\hline
\end{tabular}

Clustered Standard errors in parentheses

${ }^{* * *} p<0.01,{ }^{* *} p<0.05,{ }^{*} p<0.1$

Note: Standard errors in parentheses with *, ${ }^{* *}$ and ${ }^{* * *}$ respectively denoting signifficance at the $1 \%, 5 \%$ and $10 \%$ levels. Standard errors are clustered at the country pair level in all colummns. The estimation is performed using Poisson's pseudo-maximum likelihood estimator (PPML). Visa dummy is equal to one for trade flows between the Schengen members and Bolivia or Ecuador and zero otherwise. Ln dist. is the distance between the exporter and importer countries in logs taken from CEPIl's GeoDist database. Column 1 has no fixed effects. In column two year fixed effects are included. In column three includes pair fixed and year fixed effects while column four has country-year and year pair fixed effects. 
Table 10: Difference in differences

\begin{tabular}{|c|c|c|c|c|}
\hline VARIABLES & $\begin{array}{c}(1) \\
\text { flow } \\
\text { ECU }\end{array}$ & $\begin{array}{c}(2) \\
\text { flow } \\
\text { BOL }\end{array}$ & $\begin{array}{c}\text { (3) } \\
\text { flow } \\
\text { ECU }\end{array}$ & $\begin{array}{c}(4) \\
\text { flow } \\
\text { BOL }\end{array}$ \\
\hline visa*time dummy & $\begin{array}{c}-292.4^{* * *} \\
(47.90)\end{array}$ & $\begin{array}{c}-420.8^{\star * *} \\
(58.58)\end{array}$ & $\begin{array}{c}-230.2^{\star \star \star} \\
(62.11)\end{array}$ & $\begin{array}{c}-321.0^{* * *} \\
(52.62)\end{array}$ \\
\hline time dummy & $\begin{array}{c}-302.5^{\star * *} \\
(63.30)\end{array}$ & $\begin{array}{c}-410.3^{\star \star *} \\
(42.41)\end{array}$ & $\begin{array}{l}-29.20 \\
(70.16)\end{array}$ & $\begin{array}{l}-20.81 \\
(73.56)\end{array}$ \\
\hline visa dummy & $\begin{array}{c}361.5^{\star \star \star} \\
(36.28)\end{array}$ & $\begin{array}{c}535.9^{\star \star *} \\
(46.49)\end{array}$ & $\begin{array}{c}154.2^{* *} \\
(63.22)\end{array}$ & $\begin{array}{c}308.1^{* \star *} \\
(60.83)\end{array}$ \\
\hline GDP, origin & & & $\begin{array}{c}-0 \\
(7.80 \mathrm{e}-11)\end{array}$ & $\begin{array}{c}-0 \\
(7.82 \mathrm{e}-11)\end{array}$ \\
\hline Pop, origin & & & $\begin{array}{c}1.06 \mathrm{e}-05^{* * *} \\
(2.44 \mathrm{e}-06)\end{array}$ & $\begin{array}{c}1.10 \mathrm{e}-05^{* * *} \\
(2.44 \mathrm{e}-06)\end{array}$ \\
\hline GDP, dest. & & & $\begin{array}{c}4.88 \mathrm{e}-10^{\star \star *} \\
(9.40 \mathrm{e}-11)\end{array}$ & $\begin{array}{c}4.73 \mathrm{e}-10^{\star * *} \\
(9.31 \mathrm{e}-11)\end{array}$ \\
\hline Pop, dest. & & & $\begin{array}{c}-3.12 \mathrm{e}-07 \\
(1.04 \mathrm{e}-06)\end{array}$ & $\begin{array}{l}7.92 \mathrm{e}-08 \\
(1.03 \mathrm{e}-06)\end{array}$ \\
\hline Shared border & & & $\begin{array}{c}1,327^{\star \star \star} \\
(360.9)\end{array}$ & $\begin{array}{c}1,310^{\star \star *} \\
(360.6)\end{array}$ \\
\hline Common lang. official & & & $\begin{array}{c}827.5^{\star * *} \\
(263.8)\end{array}$ & $\begin{array}{c}855.6^{* * *} \\
(273.1)\end{array}$ \\
\hline Distance & & & $\begin{array}{c}-0.0121^{\star *} \\
(0.00506)\end{array}$ & $\begin{array}{c}-0.0122^{* *} \\
(0.00514)\end{array}$ \\
\hline Constant & $\begin{array}{c}413.3^{\star \star \star} \\
(50.36)\end{array}$ & $\begin{array}{c}452.1^{\star * *} \\
(40.11)\end{array}$ & $\begin{array}{c}-169.4^{\star \star \star} \\
(44.09)\end{array}$ & $\begin{array}{c}-183.8^{\star \star *} \\
(47.45)\end{array}$ \\
\hline $\begin{array}{l}\text { Observations } \\
R^{2}\end{array}$ & $\begin{array}{c}973,750 \\
0.000\end{array}$ & $\begin{array}{c}974,873 \\
0.000\end{array}$ & $\begin{array}{c}947,651 \\
0.003\end{array}$ & $\begin{array}{c}944,807 \\
0.003\end{array}$ \\
\hline
\end{tabular}

Standard errors in parentheses with *, ${ }^{* *}$ and ${ }^{* * *}$ respectively denoting signifficance at the $1 \%, 5 \%$ and $10 \%$ levels. The estimation is performed on trade flows at the two digit level of the Harmonized system. Standard errors are clustered by country pair. Time dummy is a dummy variable equal to one once a short-stay visa is introduced (i.e. 2003 for Ecuador and 2007 for Bolivia). Visa dummy is equal to one for trade flows between the Schengen members and Bolivia or Ecuador. Common lang. official is a dummy variable equal to one if the two countries have a common official language. Dist is the distance between the exporter and importer countries taken from CEPII's GeoDist database. 
Figure 15: USA refusal rates

\begin{tabular}{lcccc}
\hline VARIABLES & $\begin{array}{c}(1) \\
\text { tradevalue }\end{array}$ & $\begin{array}{c}(2) \\
\text { tradevalue }\end{array}$ & $\begin{array}{c}(3) \\
\text { tradevalue }\end{array}$ & $\begin{array}{c}(4) \\
\text { tradevalue }\end{array}$ \\
\hline Visas Refusal Rate, dest. & $4.100^{* * *}$ & $4.114^{* * *}$ & $-0.401^{* * *}$ & $-0.401^{* * *}$ \\
& $(1.048)$ & $(1.043)$ & $(0.0643)$ & $(0.0643)$ \\
In GDP/Pop, origin & $5.221^{* \star *}$ & -12.59 & 0.924 & 0.924 \\
& $(1.556)$ & $(19.94)$ & $(2.428)$ & $(2.428)$ \\
In GDP/Pop, dest. & $0.733^{* \star *}$ & $0.734^{* \star *}$ & $0.496^{\star * *}$ & $0.496^{* * *}$ \\
In Pop, origin & $(0.208)$ & $(0.207)$ & $(0.112)$ & $(0.112)$ \\
& $-14.62^{* *}$ & 70.14 & 6.762 & 6.762 \\
In Pop, dest. & $(7.199)$ & $(98.36)$ & $(10.74)$ & $(10.74)$ \\
& $0.903^{* * *}$ & $0.905^{* * *}$ & 0.883 & 0.883 \\
Observations & $(0.133)$ & $(0.134)$ & $(0.720)$ & $(0.720)$ \\
\hline
\end{tabular}

Note: Standard errors in parentheses with *, ${ }^{* *}$ and ${ }^{* * *}$ respectively denoting signifficance at the $1 \%, 5 \%$ and $10 \%$ levels. Standard errors are clustered at the country pair level in all colummns. The estimation is performed using Poisson's pseudo-maximum likelihood estimator (PPML). Visa dummy is equal to one for trade flows between the Schengen members and Bolivia or Ecuador and zero otherwise. Ln dist. is the distance between the exporter and importer countries in logs taken from CEPIl's GeoDist database. Column 1 has no fixed effects. In column two year fixed effects are included. In column three includes pair fixed and year fixed effects while column four has country-year and year pair fixed effects. 
Appendix D

Figure 16: Generalized difference in differences

\begin{tabular}{lc}
\hline VARIABLES & trade flow \\
\hline & \\
Visa & $-213.8^{*}$ \\
& $(148.3)$ \\
GDP, origin & $2.46 \mathrm{e}-10^{\star * *}$ \\
& $(0)$ \\
Pop, origin & $9.33 \mathrm{e}-06$ \\
& $(6.89 \mathrm{e}-06)$ \\
GDP, dest. & $6.05 \mathrm{e}-10^{\star * *}$ \\
& $(0)$ \\
Pop, dest. & $-2.45 \mathrm{e}-05^{\star * *}$ \\
& $(7.23 \mathrm{e}-06)$ \\
Constant & $559.2^{\star * *}$ \\
& $(199.2)$ \\
& \\
Observations & $6,462,792$ \\
Number of dyad_hs & 756,192 \\
$R^{2}$ & 0.000
\end{tabular}

Standard errors in parentheses with *, ${ }^{* \star}$ and ${ }^{* * *}$ respectively denoting signifficance at the $1 \%, 5 \%$ and $10 \%$ levels. The estimation is performed on trade flows at the two digit level of the Harmonized system. Standard errors are clustered by country pair. Time dummy is a dummy variable equal to one once a short-stay visa is introduced (i.e. 2003 for Ecuador and 2007 for Bolivia). Visa dummy is equal to one for trade flows between the Schengen members and Bolivia or Ecuador. Dist is the distance between the exporter and importer countries taken from CEPII's GeoDist database. 
Appendix E

Table 11: Placebo test III: Falsified visas (difference in differences)

\begin{tabular}{|c|c|c|c|c|}
\hline VARIABLES & $\begin{array}{c}(1) \\
\mathrm{CHL} \\
\text { MEX } \\
\text { Trade }\end{array}$ & $\begin{array}{c}(2) \\
\text { CRI } \\
\text { JPN } \\
\text { Trade }\end{array}$ & $\begin{array}{c}\text { (3) } \\
\text { MYS } \\
\text { ARG } \\
\text { Trade }\end{array}$ & $\begin{array}{c}(4) \\
\text { DOM } \\
\text { CHE } \\
\text { Trade }\end{array}$ \\
\hline Visa & $\begin{array}{l}438.6 \\
(278.9)\end{array}$ & $\begin{array}{l}-109.0 \\
(87.50)\end{array}$ & $\begin{array}{l}-69.92 \\
(63.76)\end{array}$ & $\begin{array}{l}299.5 \\
(190.6)\end{array}$ \\
\hline GDP, origin & $\begin{array}{c}2.48 \mathrm{e}-10^{\star *} \\
(9.76 \mathrm{e}-11)\end{array}$ & $\begin{array}{c}2.47 e-10^{\star *} \\
(9.80 e-11)\end{array}$ & $\begin{array}{c}2.45 \mathrm{e}-10^{\star *} \\
(9.76 \mathrm{e}-11)\end{array}$ & $\begin{array}{c}2.43 e-10^{\star *} \\
(9.77 e-11)\end{array}$ \\
\hline Pop, origin & $\begin{array}{l}8.56 \mathrm{e}-06 \\
(1.64 \mathrm{e}-05)\end{array}$ & $\begin{array}{l}9.22 \mathrm{e}-06 \\
(1.64 \mathrm{e}-05)\end{array}$ & $\begin{array}{l}9.50 \mathrm{e}-06 \\
(1.64 \mathrm{e}-05)\end{array}$ & $\begin{array}{l}9.89 \mathrm{e}-06 \\
(1.64 \mathrm{e}-05)\end{array}$ \\
\hline GDP, dest. & $\begin{array}{c}6.07 \mathrm{e}-10^{\star * *} \\
(1.06 \mathrm{e}-10)\end{array}$ & $\begin{array}{c}6.06 \mathrm{e}-10^{\star \star *} \\
(1.06 \mathrm{e}-10)\end{array}$ & $\begin{array}{c}6.04 \mathrm{e}-10^{\star \star \star} \\
(1.06 \mathrm{e}-10)\end{array}$ & $\begin{array}{c}6.02 \mathrm{e}-10^{\star \star *} \\
(1.06 \mathrm{e}-10)\end{array}$ \\
\hline Pop, dest. & $\begin{array}{l}-2.55 e-05 \\
(1.68 e-05)\end{array}$ & $\begin{array}{c}-2.47 e-05 \\
(1.68 e-05)\end{array}$ & $\begin{array}{c}-2.44 \mathrm{e}-05 \\
(1.67 \mathrm{e}-05)\end{array}$ & $\begin{array}{l}-2.40 \mathrm{e}-05 \\
(1.67 \mathrm{e}-05)\end{array}$ \\
\hline $\begin{array}{l}\text { Observations } \\
R^{2} \\
\text { Number of dyad_hs }\end{array}$ & $\begin{array}{c}6,462,792 \\
0.000 \\
756,192\end{array}$ & $\begin{array}{c}6,462,792 \\
0.000 \\
756,192\end{array}$ & $\begin{array}{c}6,462,792 \\
0.000 \\
756,192\end{array}$ & $\begin{array}{c}6,462,792 \\
0.000 \\
756,192\end{array}$ \\
\hline
\end{tabular}

Clustered standard errors in parentheses

$$
{ }^{* * *} p<0.01,{ }^{* *} p<0.05,{ }^{*} p<0.1
$$

Note: The estimation is performed on trade flows at the two digit level of the Harmonized system. Standard errors are clustered by country pair. The first country replaces Ecuador and the second country replaces Bolivia. Time dummy is a dummy variable equal to one once a short-stay visa is introduced (i.e. 2003 for the first country and 2007 for the second). Visa dummy is equal to one for trade flows between the Schengen members and one of the two countries in the header of the column. 
Table 12: World Bank income categories

\begin{tabular}{|c|c|c|}
\hline \multicolumn{3}{|c|}{ Low-income economies ( $\$ 1,045$ or less) } \\
\hline Afghanistan & Gambia,The & Niger \\
\hline Benin & Guinea & Rwanda \\
\hline Burkina Faso & Guinea-Bisau & Sierra Leone \\
\hline Burundi & Haiti & Somalia \\
\hline Cambodia & Korea, Dem Rep. & South Sudan \\
\hline Central African Republic & Liberia & Tanzania \\
\hline Chad & Madagascar & Togo \\
\hline Comoros & Malawi & Uganda \\
\hline Congo, Dem. Rep & Mali & Zimbabwe \\
\hline Eritrea & Mozambique & Ethiopia \\
\hline \multicolumn{3}{|l|}{ Nepal } \\
\hline \multicolumn{3}{|c|}{ Lower-middle-income economies $(1,046$ to $\$ 4,125)$} \\
\hline Armenia & Indonesia & Samoa \\
\hline Bangladesh & Kenya & Sao Tome and Principe \\
\hline Bhutan & Kiribati & Senegal \\
\hline Bolivia & Kosovo & Solomon Islands \\
\hline Cabo Verde & KyrgyzRepublic & Sri Lanka \\
\hline Cameroon & Lao PDR & Sudan \\
\hline Congo,Rep. & Lesotho & Swaziland \\
\hline Cote d'Ivoire & Mauritania & Syrian Arab Republic \\
\hline Djibouti Micronesia,Fed. Sts. & Tajikistan & \\
\hline Egypt,Arab Rep. & Moldova & Timor-Leste \\
\hline El Salvador & Morocco & Ukraine \\
\hline Georgia & Myanmar & Uzbekistan \\
\hline Ghana & Nicaragua & Vanuatu \\
\hline Guatemala & Nigeria & Vietnam \\
\hline Guyana & Pakistan & West Bank and Gaza \\
\hline Honduras & Papua New Guinea & Yemen,Rep. \\
\hline India & Philippines & Zambia \\
\hline \multicolumn{3}{|c|}{ Upper-middle-income economies $(4,126$ to $\$ 12,735)$} \\
\hline Albania & Fiji & Namibia \\
\hline Algeria & Gabon & Palau \\
\hline American Samoa & Grenada & Panama \\
\hline Angola & Iran,Islamic Rep. & Paraguay \\
\hline Azerbaijan & Iraq & Peru \\
\hline Belarus & Jamaica & Romania \\
\hline Belize & Jordan & Serbia \\
\hline
\end{tabular}


Do visas hinder international trade in goods?

$\begin{array}{lll}\text { Bosnia and Herzegovina } & \text { Kazakhstan } & \text { South Africa } \\ \text { Botswana } & \text { Lebanon } & \text { St. Lucia } \\ \text { Brazil } & \text { Libya } & \text { St. Vincent and the Grenadines } \\ \text { Bulgaria } & \text { Macedonia,FYR } & \text { Suriname } \\ \text { China } & \text { Malaysia } & \text { Thailand } \\ \text { Colombia } & \text { Maldives } & \text { Tonga } \\ \text { Costa Rica } & \text { Marshall Islands } & \text { Tunisia } \\ \text { Cuba } & \text { Mauritius } & \text { Turkey } \\ \text { Dominica } & \text { Mexico } & \text { Turkmenistan } \\ \text { Dominican Republic } & \text { Mongolia } & \text { Tuvalu } \\ \text { Ecuador } & \text { Montenegro } & \end{array}$

High-income economies $(\$ 12,736$ or more)

\begin{tabular}{lll}
\hline Andorra & Germany & Poland \\
Antigua and Barbuda & Greece & Portugal \\
Argentina & Greenland & Puerto Rico \\
Aruba & Guam & Qatar \\
Australia & Hong Kong SAR,China & Russian Federation \\
Austria & Hungary & San Marino \\
Bahamas,The & Iceland & Saudi Arabia \\
Bahrain & Ireland & Seychelles \\
Barbados & Isle of Man & Singapore \\
Belgium & Israel & Sint Maarten (Dutch part) \\
Bermuda & Italy & Slovak Republic \\
Brunei Darussalam & Japan & Slovenia \\
Canada & Korea,Rep. & Spain \\
Cayman Islands & Kuwait & St.Kitts and Nevis \\
Channel Islands & Latvia & St. Martin (French part) \\
Chile & Liechtenstein & Sweden \\
Croatia & Lithuania & Switzerland \\
Curaçao & Luxembourg & Taiwan,China \\
Cyprus & Macao SAR,China & Trinidad and Tobago \\
Czech Republic & Malta & Turks and Caicos Islands \\
Denmark & Monaco & United Arab Emirates \\
Estonia & Netherlands & United Kingdom \\
Equatorial Guinea & New Caledonia & United States \\
Faeroe Islands & New Zealand & Uruguay \\
Finland & Northern Mariana Islands & Venezuela,RB \\
France & Norway & Virgin Islands (U.S.) \\
French Polynesia & Oman & \\
& &
\end{tabular}




\section{Bibliography}

Alvarez, F., ANd R. E. Lucas JR (2007): "General equilibrium analysis of the Eaton-Kortum model of international trade," Journal of monetary Economics, 54(6), 1726-1768.

ANDERSON, J. E. (1979): "A theoretical foundation for the gravity equation," American Economic Review, 69(1), 106-116.

ANDERSON, J. E., AND E. VAN WINCOOP (2003): "Gravity with gravitas: a solution to the border puzzle," American Economic Review, 93(1), 170-192.

Arkolakis, C., A. Costinot, and A. Rodríguez-Clare (2012): "New Trade Models, Same Old Gains?," American Economic Review, 102(1), 94-130.

BALDWIN, R., AND D. TAGLIONI (2006): "Gravity for dummies and dummies for gravity (equations)," NBER Working Paper, 12516.

ChANEY, T. (2008): "Distorted gravity: the intensive and extensive margins of international trade," The American Economic Review, 98(4), 1707-1721.

Charbonneau, K. (2012): "Multiple fixed effects in nonlinear panel data models," Unpublished manuscript.

CHEN, B., AND D. S. JACKS (2012): "Trade, variety, and immigration," Economics Letters, 117(1), 243-246.

CRISteA, A. (2011): "Buyer-seller relationships in international trade: Evidence from US States' exports and business-class travel," Journal of International Economics, 84(2), 207220.

DekLe, R., J. EATON, and S. Kortum (2007): "New approaches to international trade. Unbalanced trade," The American economic review, 97(2), 351-355.

(2008): "Global rebalancing with gravity: measuring the burden of adjustment," Discussion paper, National Bureau of Economic Research.

EAton, J., And S. Kortum (2002): "Technology, Geograpy and Trade," Econometrica, 70(5), 1741-1779.

FERNÁNDEZ-VAL, I., AND M. WeIDNER (2013): "Individual and time effects in nonlinear panel models with large N, T," arXiv preprint arXiv:1311.7065.

Gaulier, G., And S. Zignago (2010): "BACI: International Trade Database at the ProductLevel. The 1994-2007 Version," Working Papers 2010-23, CEPII.

Genc, M., M. Gheasi, P. NiJkamp, and J. Poot (2012): "9. The impact of immigration on international trade: a meta-analysis," Migration Impact Assessment: New Horizons, p. 301.

GIRMA, S., AND Z. YU (2002): "The link between immigration and trade: Evidence from the UK," Review of World Economics, 138(1), 115-130. 
GoULD, D. M. (1994): "Immigrant links to the home country: Empirical implications for U.S. bilateral trade flows," Review of Economics and Statistics, 76(2), 302-316.

HEAD, K., AND T. MAYER (2013): "Gravity equations: Workhorse, toolkit, and cookbook," Handbook of international economics, 4.

HEAD, K., AND J. RiES (1998): "Immigration and trade creation: econometric evidence from Canada," Canadian Journal of Economics / Revue canadienne d'Economie, 31(1), 47-62.

Jochmans, K. (2015): "Two-way models for gravity," Sciences Po Department of Economics,Discussion paper 2015-03.

KULENDRAN, N., AND K. WILSON (2000): "Is there a relationship between international trade and international travel?," Applied Economics, 32(8), 1001-1009.

Melitz, M. J., AND G. I. OtTAVIANo (2008): "Market size, trade, and productivity," The review of economic studies, 75(1), 295-316.

Neumayer, E. (2011): "On the detrimental impact of visa restrictions on bilateral trade and foreign direct investment," Applied geography, 31(3), 901-907.

OXFORD ECONOMICS, U. (2012): "The return on investment of U.S. business travel," USA Travel Association and Destination and Travel Foundation, (17991).

Parsons, C., ANd P.-L. VÉZINA (2014): "Migrant Networks and Trade: The Vietnamese Boat People as a Natural Experiment," Economics Working Paper, 705.

PoOle, J. (2010): "Business travel as an input to international trade," UC Santa Cruz.

RAUCH, J. E. (1999): "Networks versus markets in international trade," Journal of International Economics, 48(1), 7 - 35.

RAUCH, J. E., AND V. TRINDAdE (2002): "Ethnic chinese networks in international trade," Review of Economics and Statistics, 84(1), 116-130.

Santos Silva, J., and S. TenReyro (2006): "The log of gravity," Review of Economics and Statistics, 88(4), 641-658.

SHAN, J., AND K. WILSON (2001): "Causality between trade and tourism: empirical evidence from China," Applied Economics Letters, 8(4), 279-283.

Tinbergen, J. (1962): Shaping the world economy. Twentieth Century Fund New York.

WESTERLUND, J., AND F. WILHELMSSON (2009): "Estimating the gravity model without gravity using panel data," Applied Economics, 43(6), 641-649. 